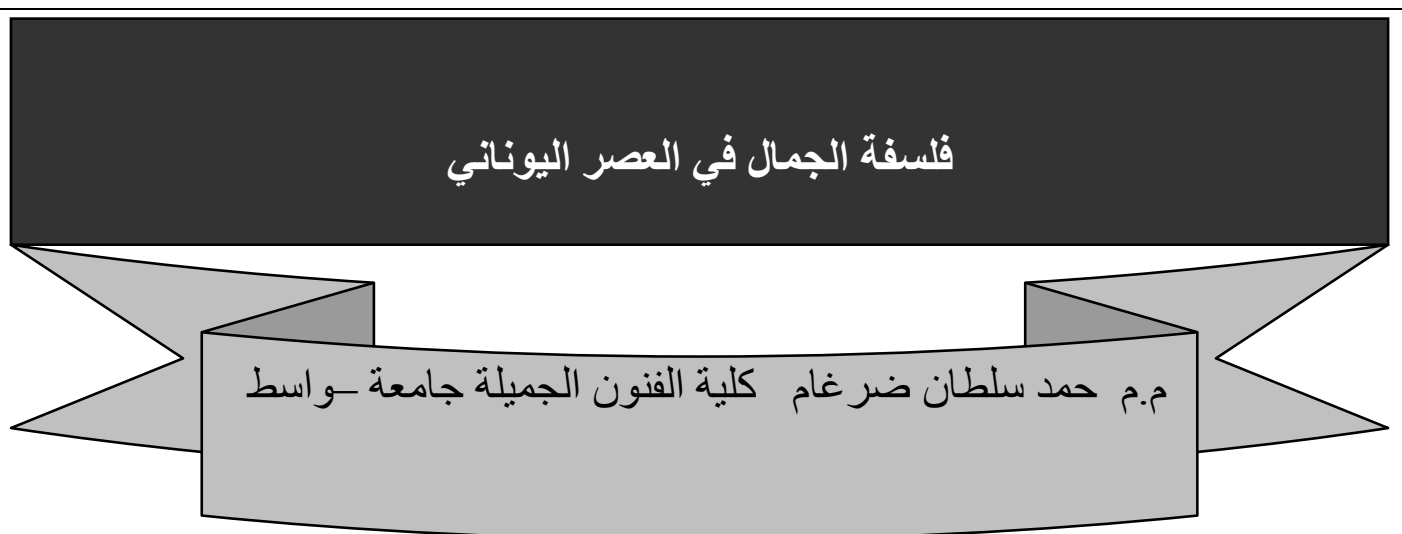

تبينت الملامح الجمالية في الفكر اليوناني القديم منذالبدايات الأولى في القرن العاشر ق. م ، في

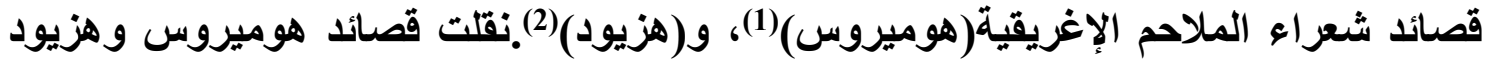

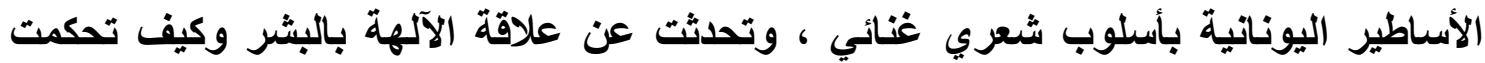

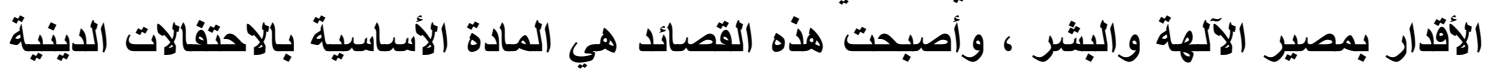

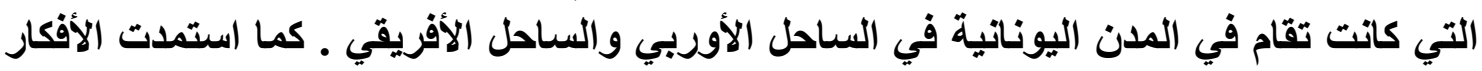
القلسفية الكثير من قوانينها من هذه الأساطير. يمكن تقسم تطور القلسفة اليونانية إلى عدة مراحل-: المرحلة الأولى : وهي بدايات الفكر الفلسفي اليوناني ويمكن حصرها-:

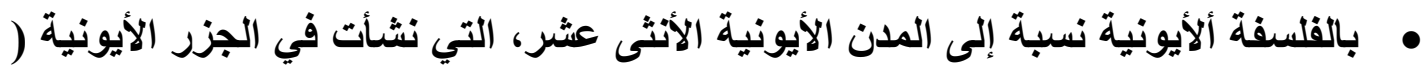

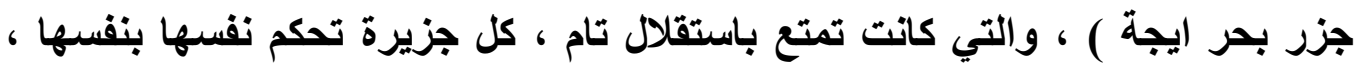

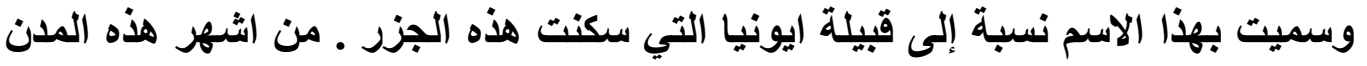

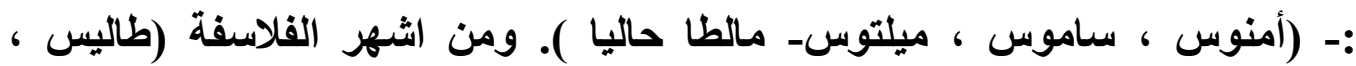

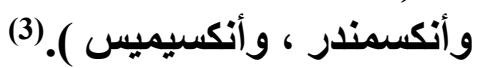
الفلسفة الأيلية ، نسبة إلى مدينة إيليا وهي مدينة يونانية نشأت في جنوب ( أيطاليا حاليا

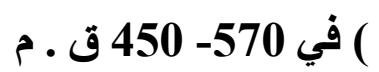
الفلسفة الفثاغورية نسبة إلى الفيلسوف (فيثاغورس) ، والتي نشأت في شبه جزيرة ايطاليا

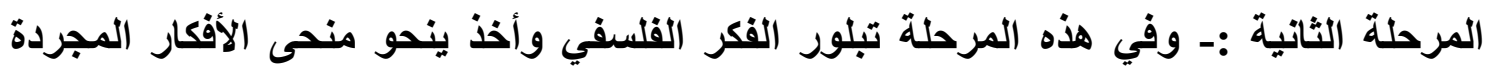
ويبتعد عن الفكر الأسطوري .ويمكن أن تحصر في هذه المرحلة المدارس الفلسفية التالية-:

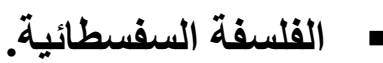


• القلسفة المثالية ( فلسفة سقراط و افلاطون)

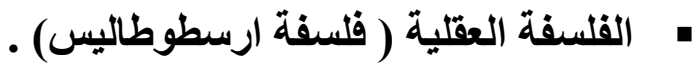

المرحلة الثالثة :- المرحلة التي تأثر فيها الفكر الفلسفي اليوناني بالأفكار الثرقية ، ويمكن

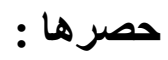

$$
\begin{aligned}
& \text { • القلسفة بالهرلنتية. } \\
& \text { • القلسفة الرومانية. } \\
& \text { • القلسفة الأيونية } \\
& \text { الفلاسفة اليونانيون الايونة }
\end{aligned}
$$

طاليس Thales

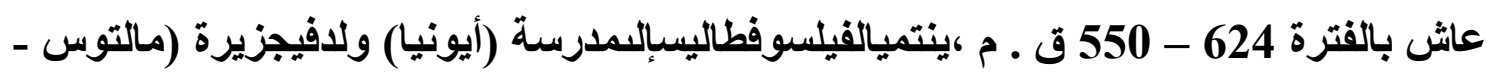

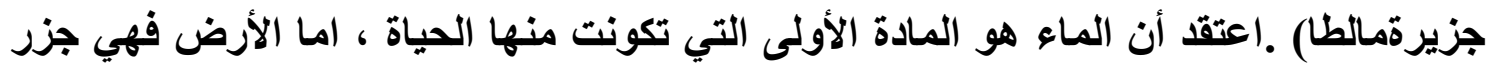

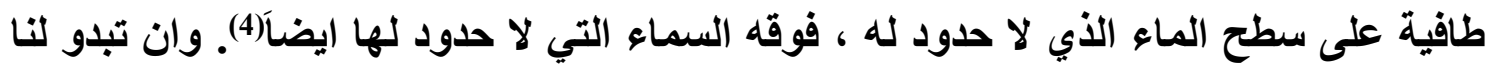

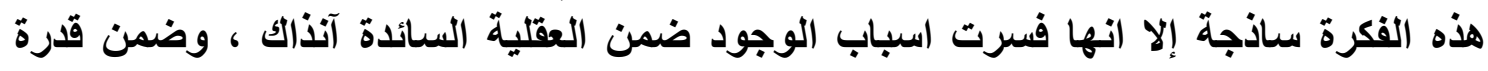

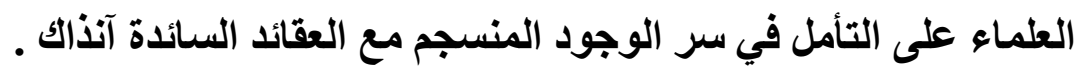

يعتقد طاليس ان جميع ما في الكون يصدر عن أصل واحد الذي هو الماء ، والاختلاف الظاهر

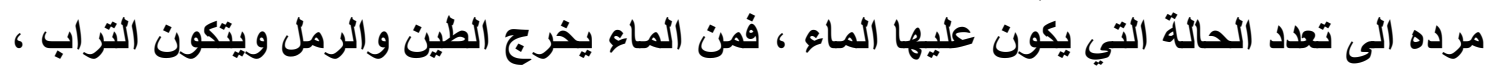

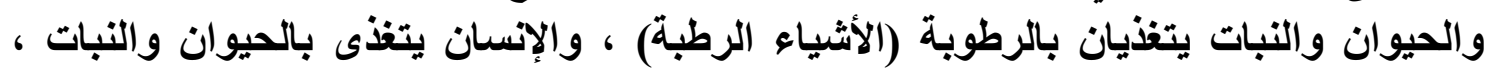

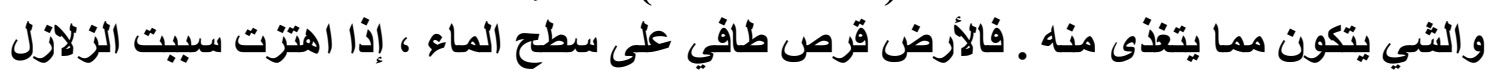

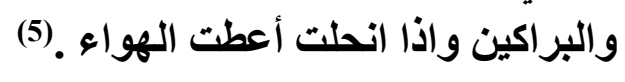

Anaxemander أنكسمندر

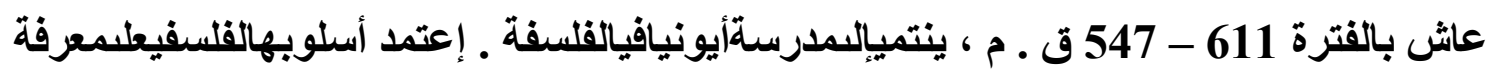

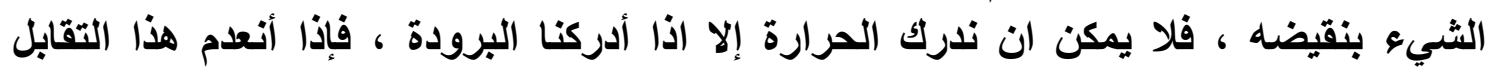

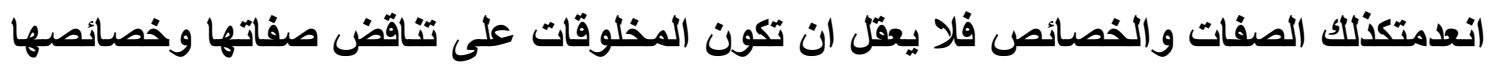

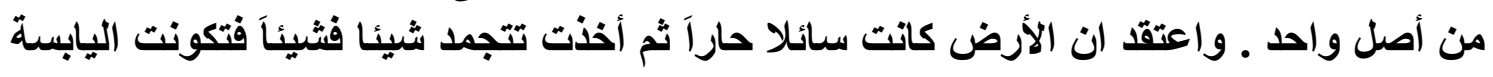

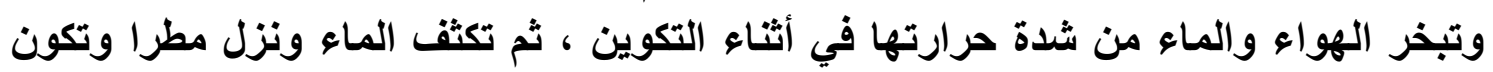

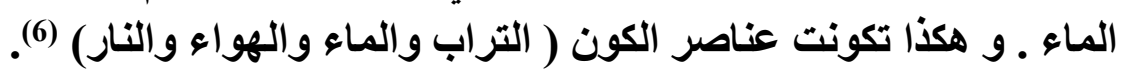


اما المخلوقات فأصلها من الرطوبة التي تكون النسبة الكبيرة من جسمها ، وخرجت جميعا من

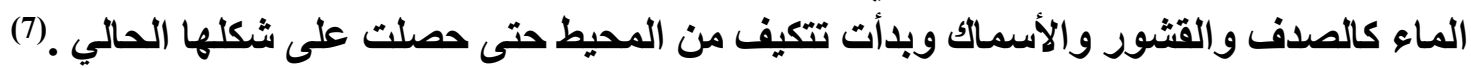

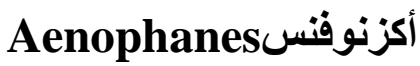

عاش في إيليا* ، ينتمي إلى القلسفة الإيلية(8) ، وهو من الفلاسفة الأين رفضوا فكرة الشرك في العقيدة الدينية الوثية لليونان القديم ، هاجم افكار شعراء الميلية الماحم هوميروس وهزيود الذين

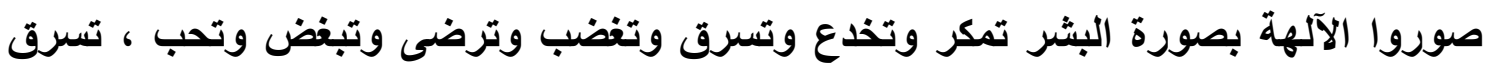

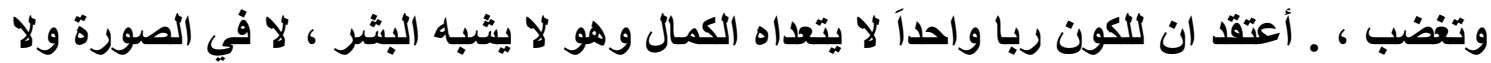

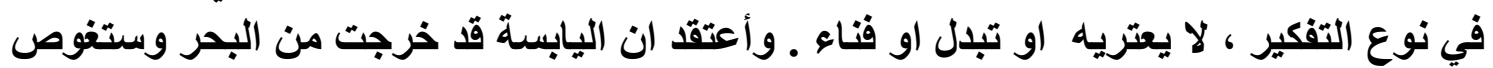

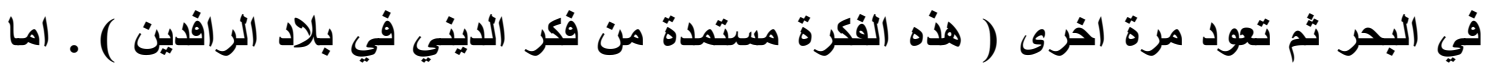

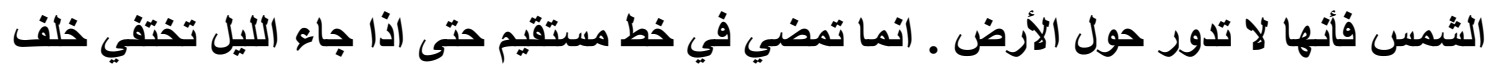

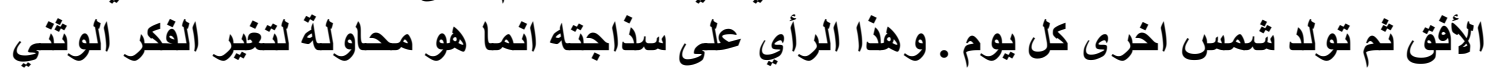

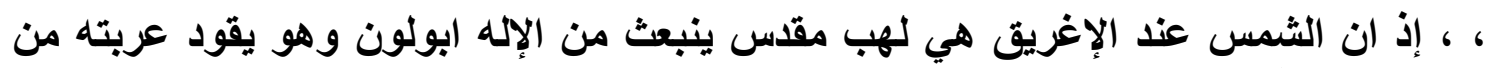

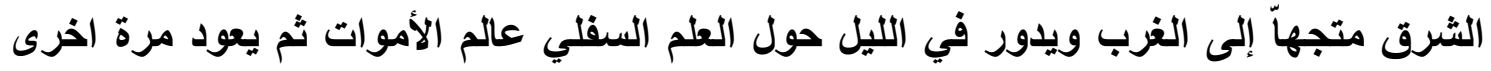

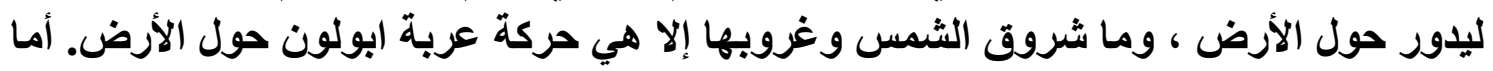

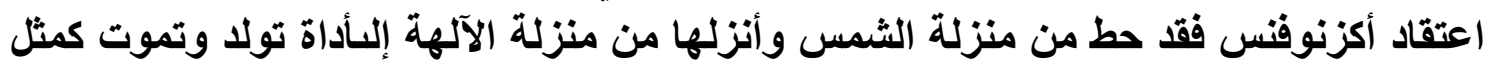
كل الكائنات الحية.

\section{Parrnenides بارميندس}

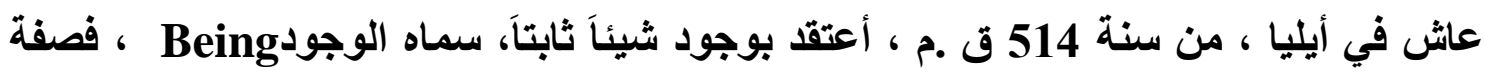

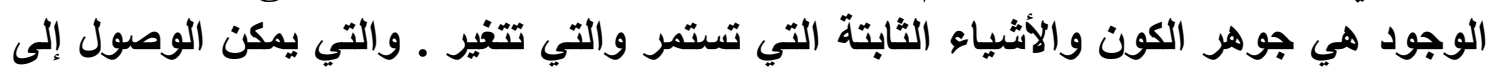

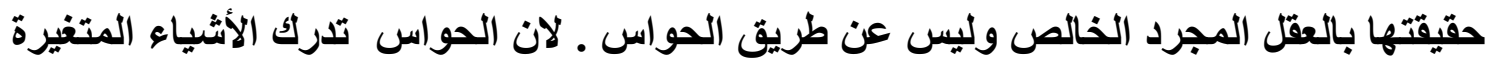

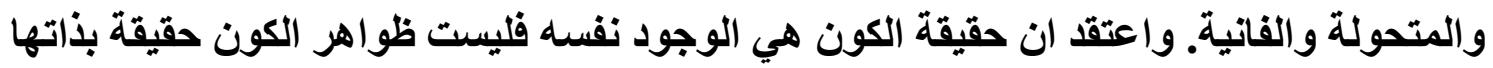

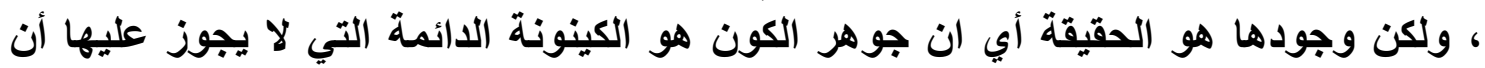

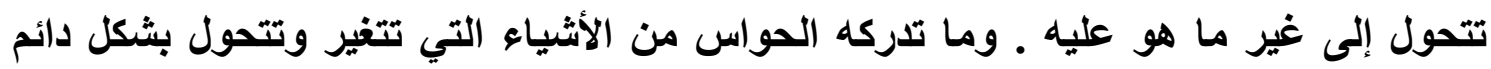

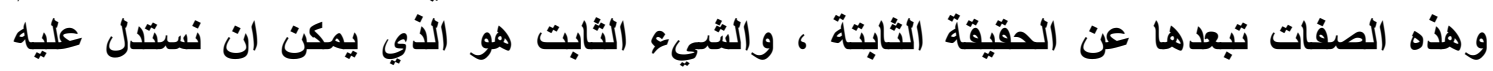

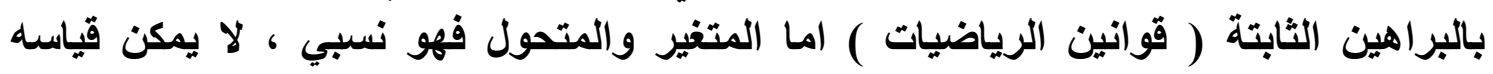

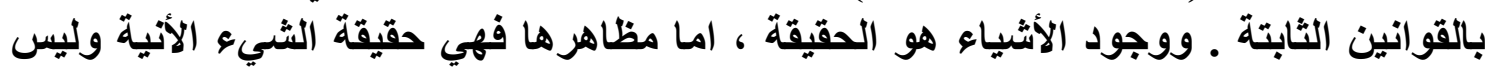

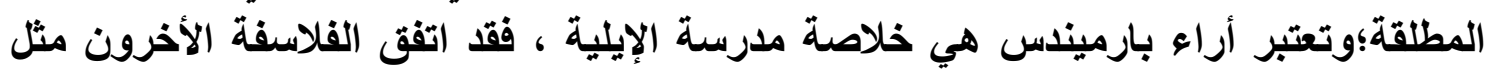

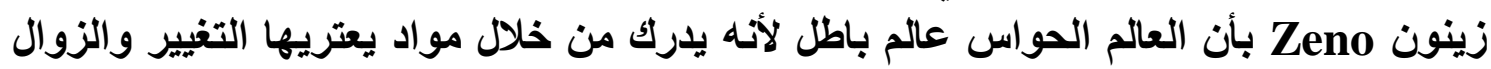

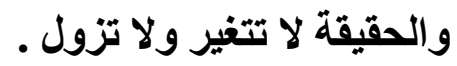


لقد خطت القلسفة الإيلية بالفكر الإنساني خطوة منسجمة نحو توحيد الحقيقة ـ فقد جردث الفكر

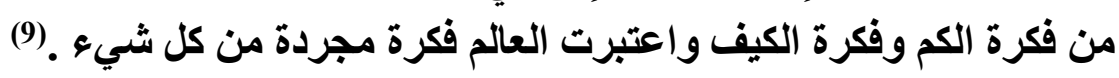
القلسفة الفيثاغورية

تأسست هذه المدرسة على يد فيثاغورس الأي ولا في جزيرة ساموس وهاجر إلى الثرق في

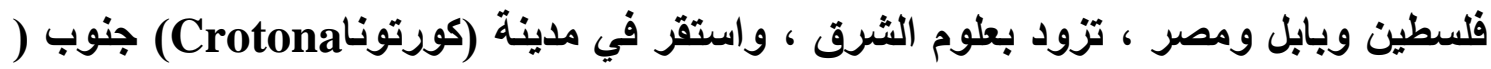

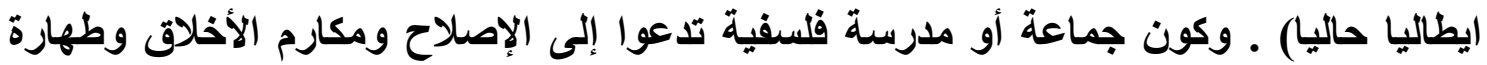

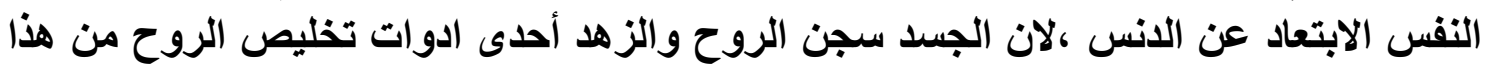

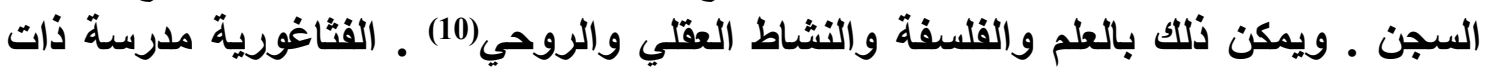

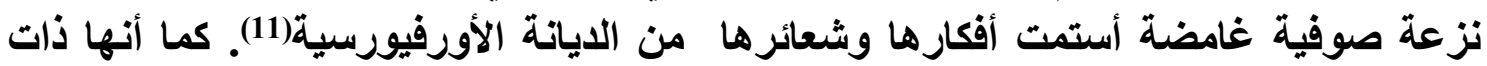

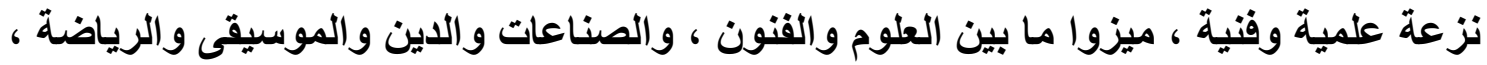
وابتكروا سبعة وأربعون نظرية في الهندسة والرياضيات ، كما أولى للرياضة البدنية أهمية خاصة.

أعتقد فيثاغورس أن كل شيء يمكن أن يارك بالحواس ، التي لا يمكن الركون اليها لأنها نسبية

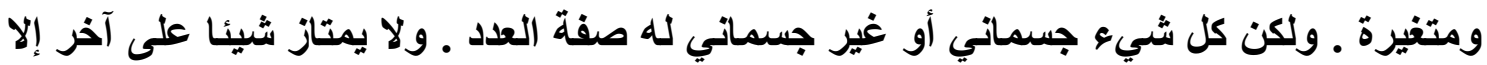

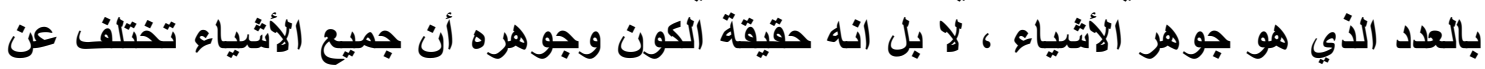

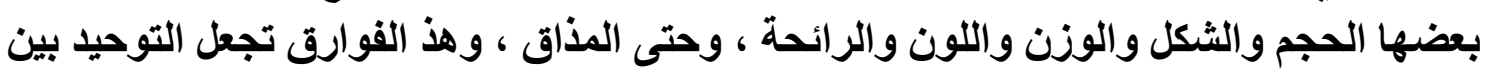

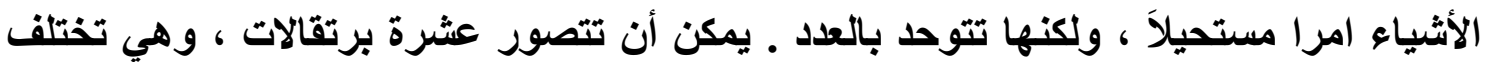

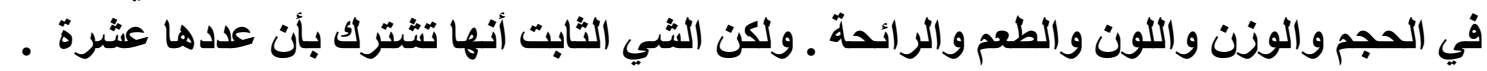

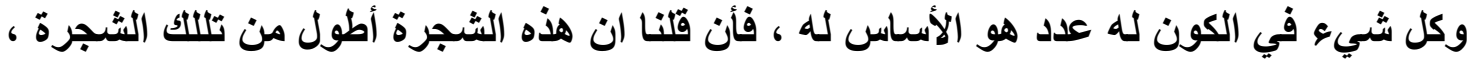

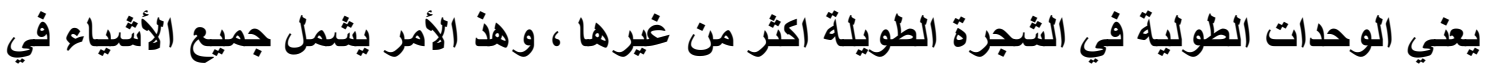

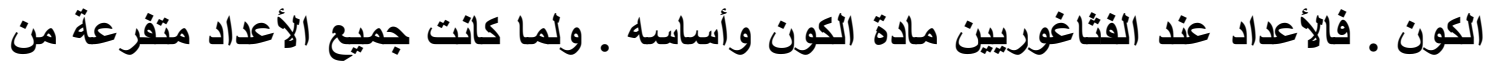

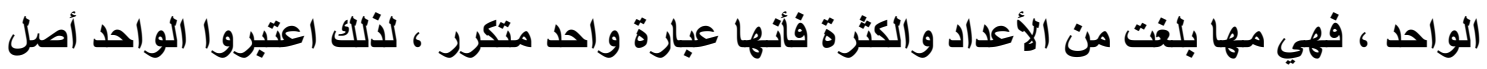
الوجود عنه نشأ وتثطور.

والأعداد تنقسم إلى اعداد فردية وزوجية ، واعتبرواذلك علة انقسام الوجود إلى المتقابلات

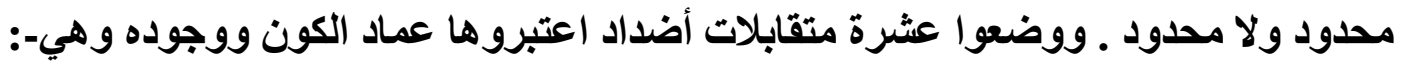
الفردي والزوجي ، المحدود واللامحدود ، الواحد والكثير ، اليمين واليسار ، الأكر والأنثى ، المستقيم والمنحني ، السكون والحركة ، النور والظلمة ، الخير والثر ، المربع ولئ والمستطيل.

والموسيقى عبارة عن أعداد من النغمات تفصل بينها أبعاد زمنية ، وهي موجات صوتية

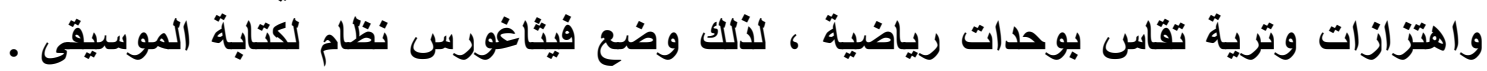


وتحويلها من اصوات إلى رموز. ولعل مبالغتهم في الأعداد دفعهم للخلط بين الحساب والهندسة .

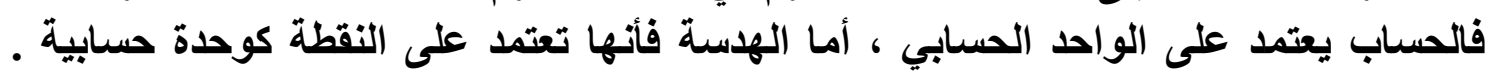
فالعدد يتكون من آحاد وعشرات ومئات والالوف ، والخط المستقيم يتكون من نقط ، وليس لللقط التطا

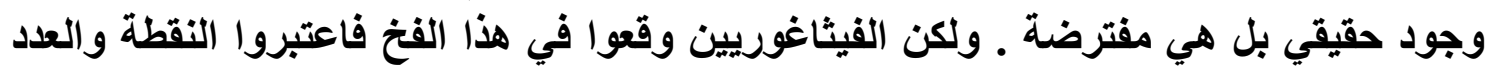
شيء واحد.

اشتهر الفثاغوريين بالرموز والألغاز ، للتشتر بالحكمة فيما بينهم ، ليستروا مناقشتهم من

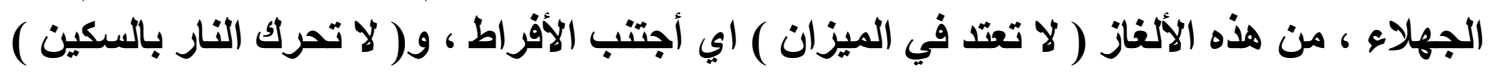

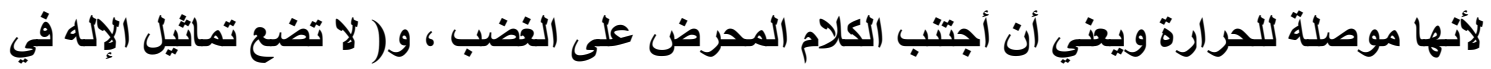

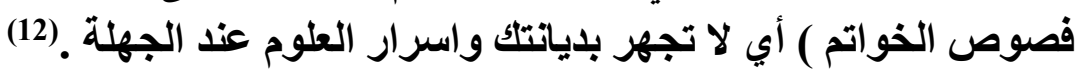

أستخدم الفيثاغوريون علم الرياضيات والموسيقى ، واعتبروها أحد أهم الوسائل في ترويض النفس وتطهيرها ـ كان فيثاغورس يمارس الموسيقى وهو الأي وضع الأساس الرياضي للسلم

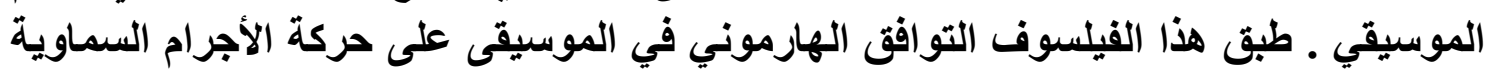
وهو صاحب فكرة ائتلاف الأضداد و التوافق بين الأضداد ويعتقد أن هناك وجودئين الكين

$$
\begin{array}{ll}
\text { الوجود المعقول } & 1 . \\
\text { المحسوس } & \text { الوجود }
\end{array}
$$

وصر اع الأضداد يهرف في النهاية إلى حدوث ائتلاف ووسط رياضي بين النقيضين ـ وكاتت هذه

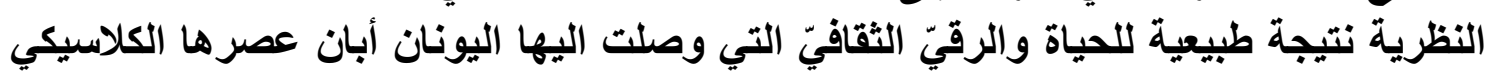
أثتاء حكم بركليس ـ حيث التوازن والاعتدال والانسجام والأسلوب الهندي وفي في كل ميادين الحياة

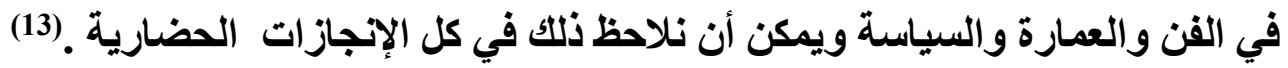

Empedocles أمبذقليسس.

ولا في صقلية سنة 490 ق.م. ـ أعتقد أن الكون كان مزيجا من الأضداد الأربعة ـ ( الحار والبارد

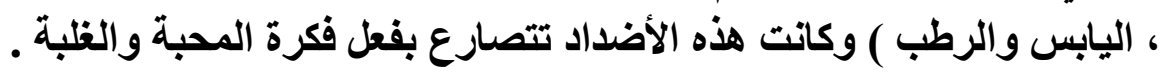

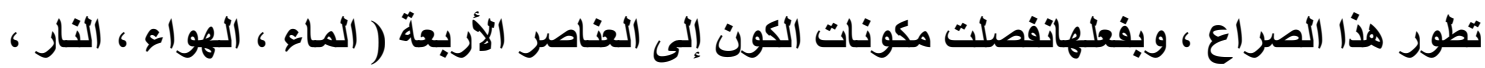

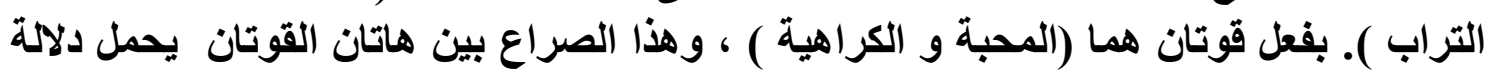

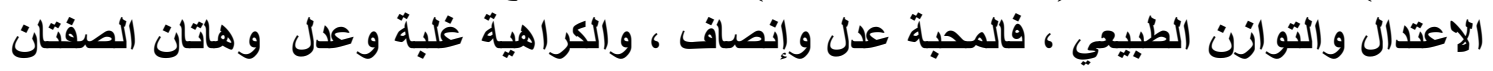

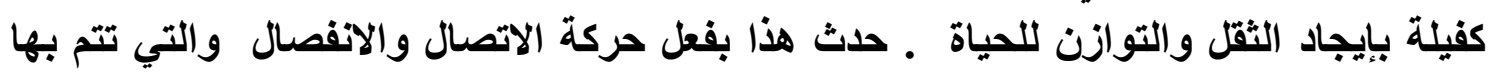

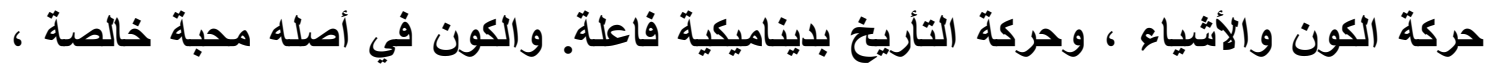

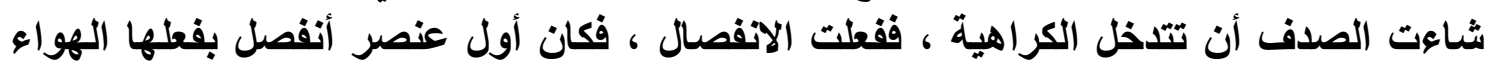




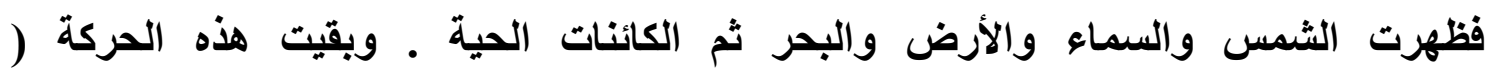

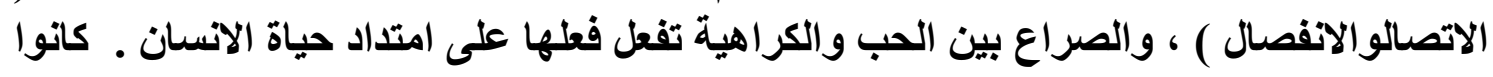

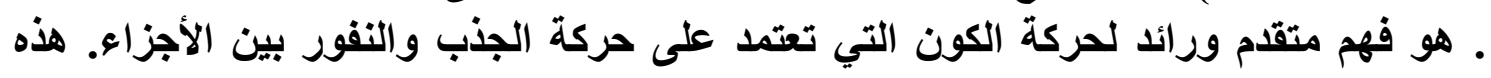

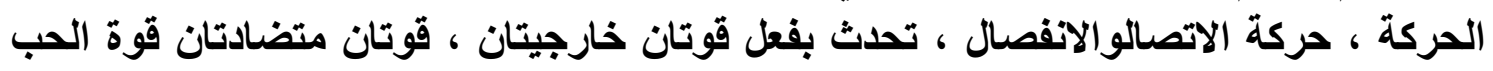

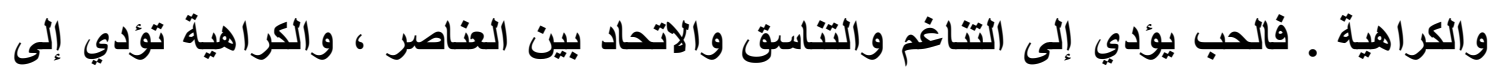

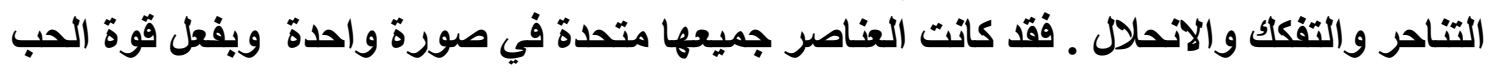

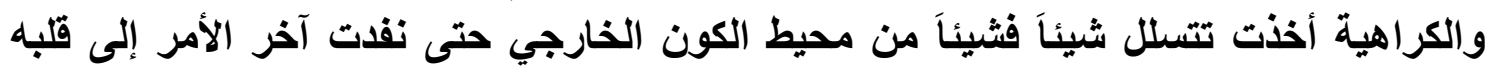

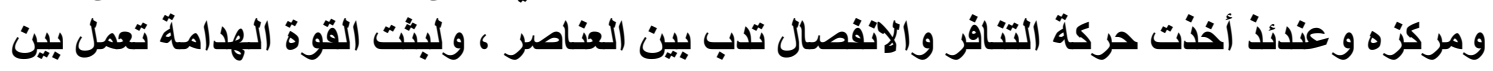

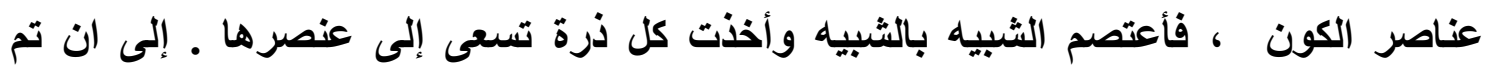

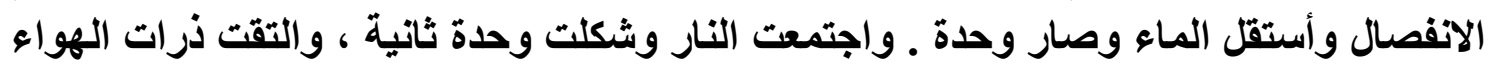

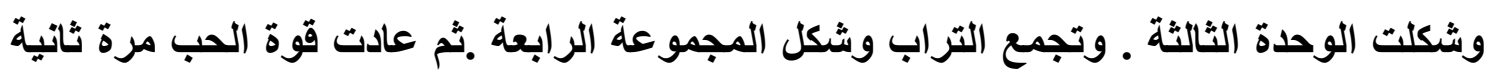

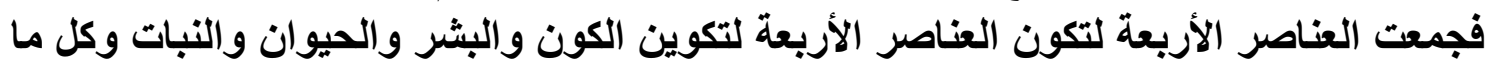

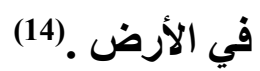

إن هذه النظرية التي تنسجم تماما مع الفكر اليوناني كاتت قاعدة مهمة لنظرية الجمال التي

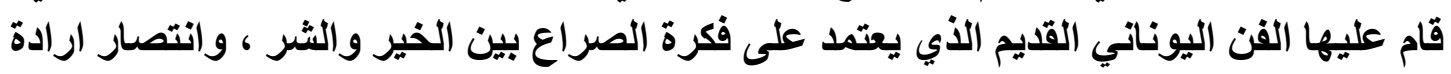

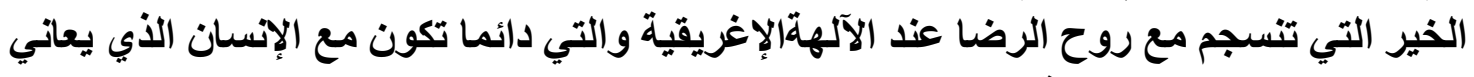

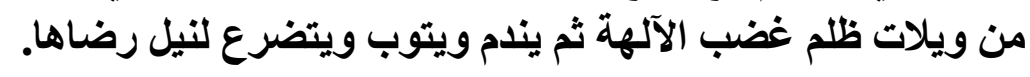

\section{هيروقليس Heracleitus}

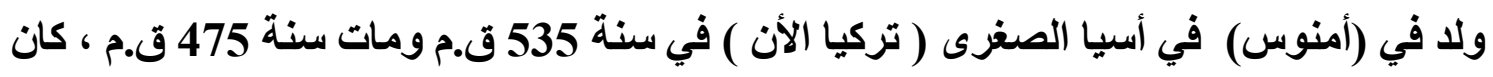

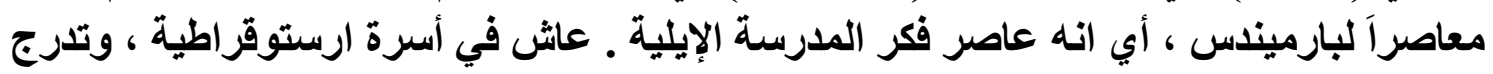

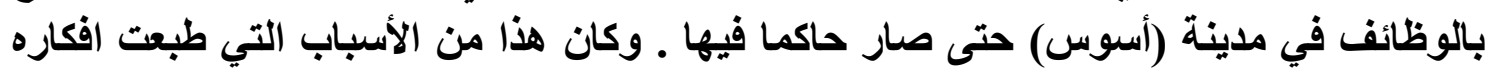

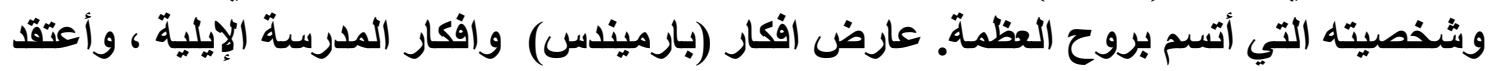

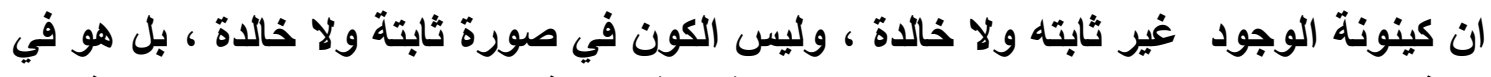

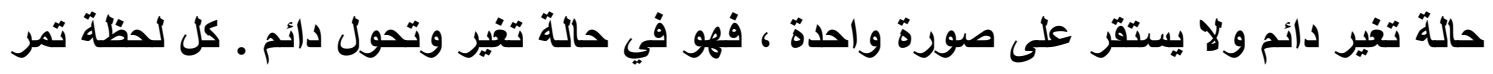

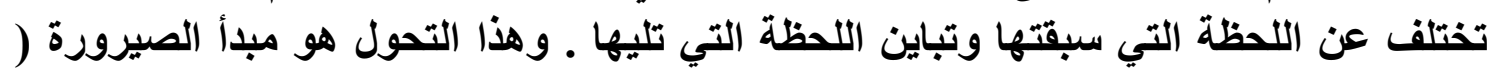

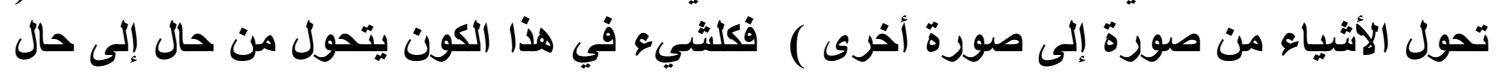

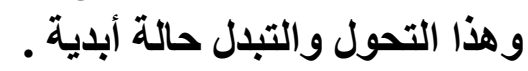

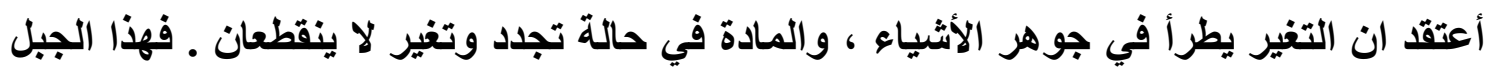

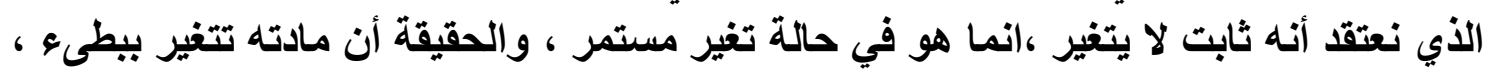

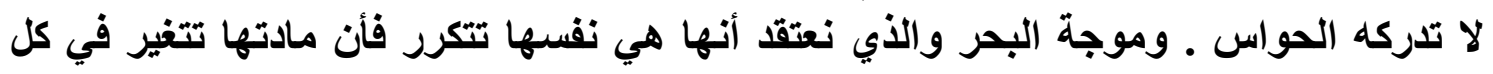


لحظة ، فتتدفق منه مواد وتخرج منه مواد ـ والجبل اليوم ليس هو جبل الأمس ولن يكون نفسه

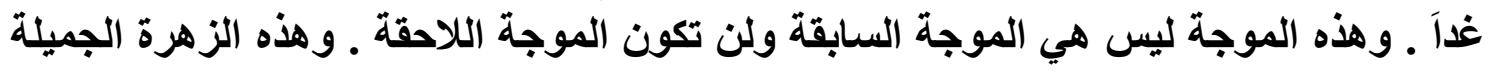

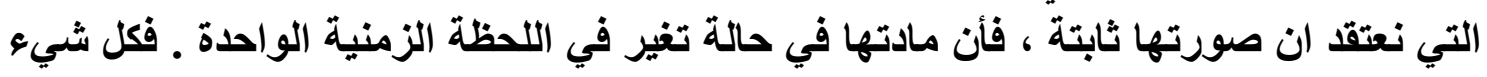

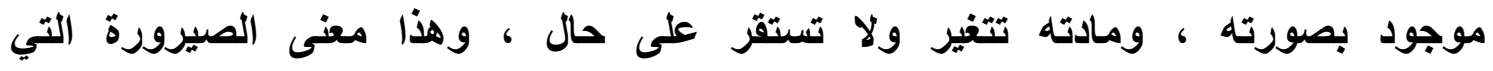
يعتقد ها(هيروقليدس) جوهر الكون .

فاللحظة لا يمكن أن تعاش مرتين وهو يعتقد ان كل شيء يجري يتغير يمر ويختفي دون عودة .

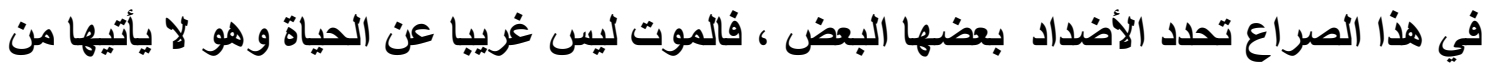

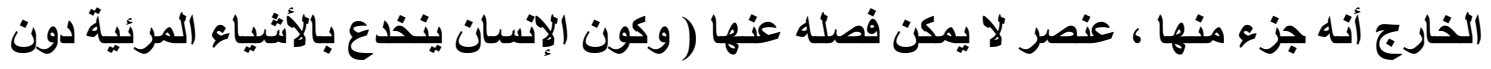

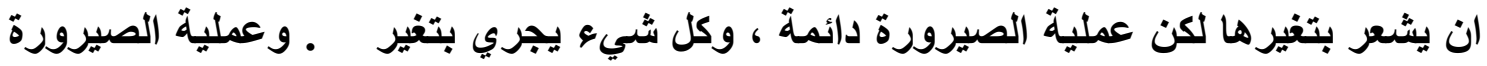

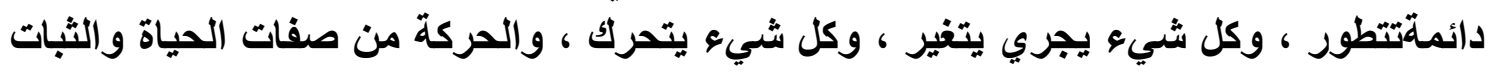

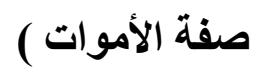

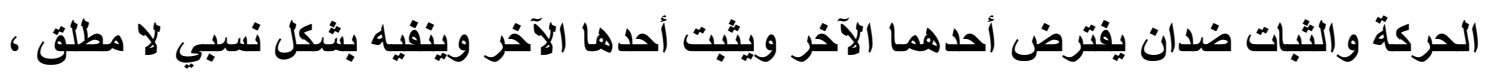

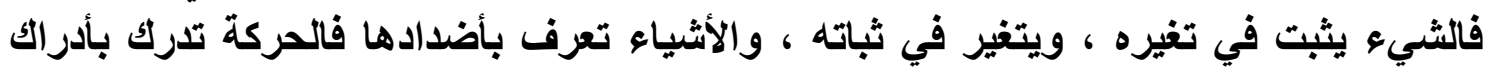

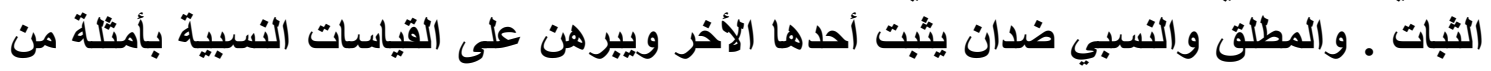

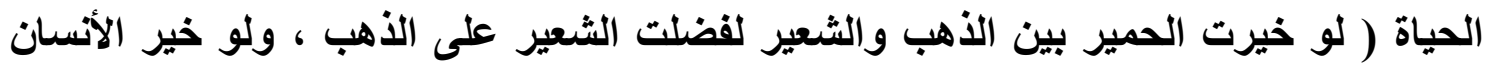

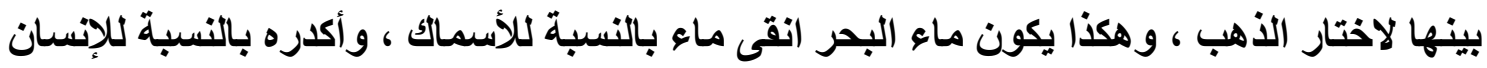

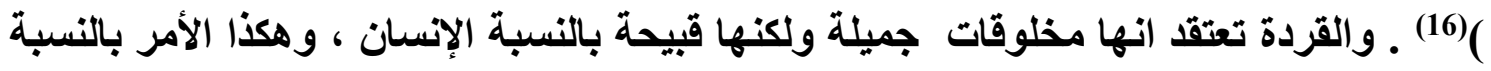

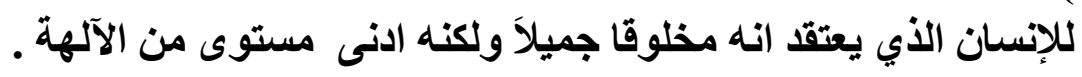

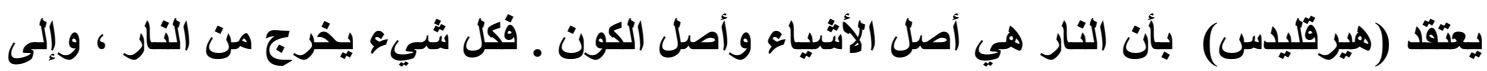

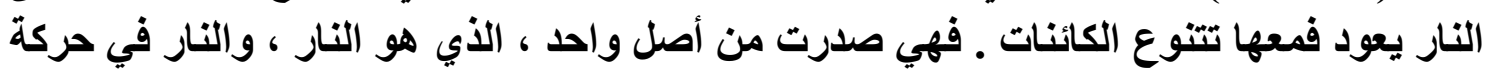

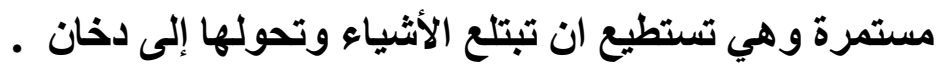
أعثقد ان الكون تكون عندما تحولت النار إلى هواء ، وعندما تحول الهواء إلى ماء ، والماء إلى هاء

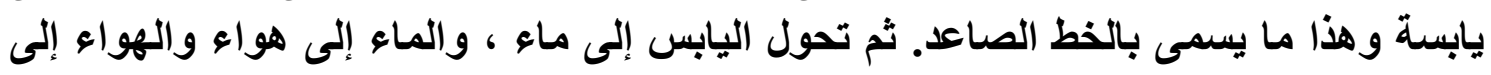

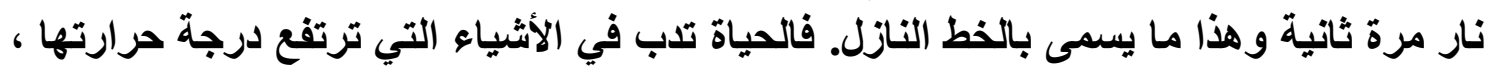

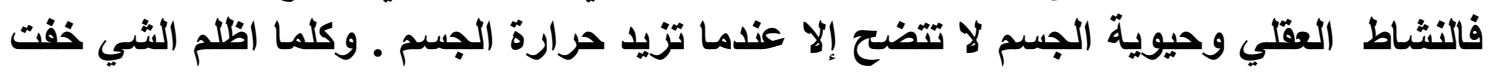

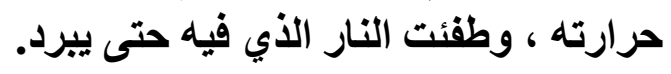

و ينكر أن ترتقي الحواس إلى مرتبة العقل والمعرفة ، أنما هي أدوات يستعين بها العقل للوصول

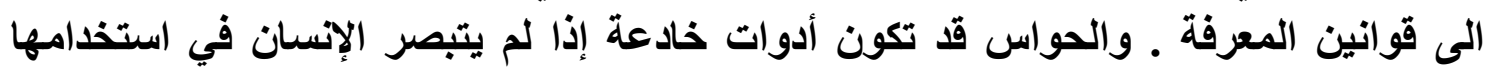


،لأنها قد لا تدرك المتغيرات التي تحصل في الأثياء والتي لا يمكن إداركها في كثير من الأحيان إلا بواسطة العقل المجرد . (17)

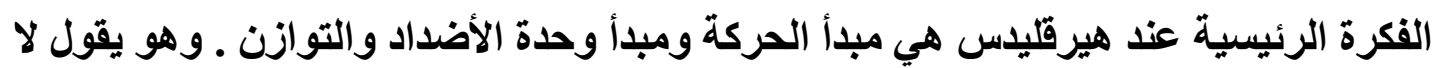

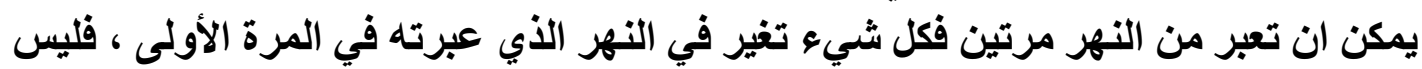

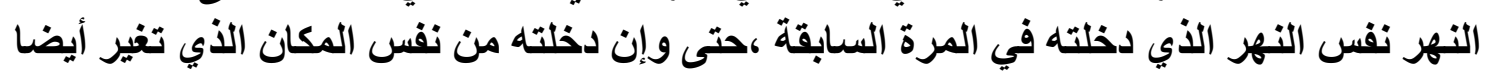

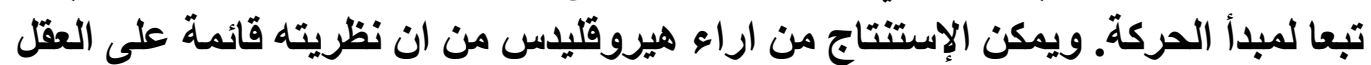

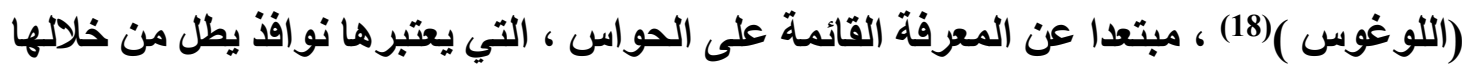

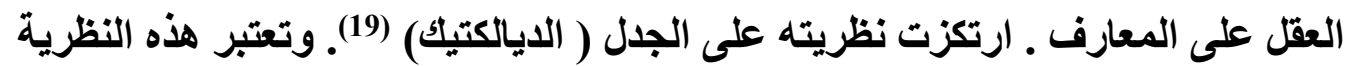

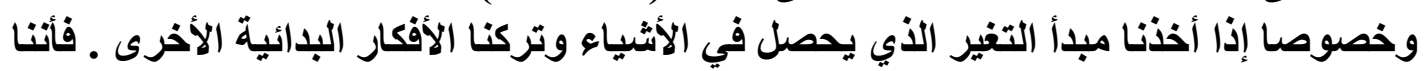
امام اهم النظريات العلمية الرائدة التي اكتثفها الفكر الإنساني والذي الذي يعمل بها الأبها العلم الحديث الأن الأن

الفلسفة السفسطائية

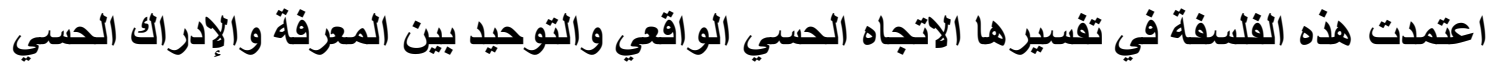

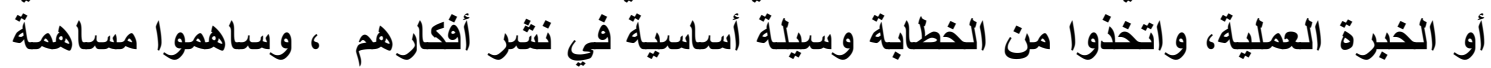

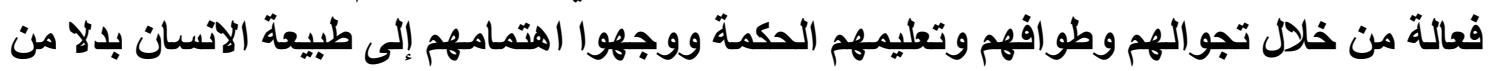

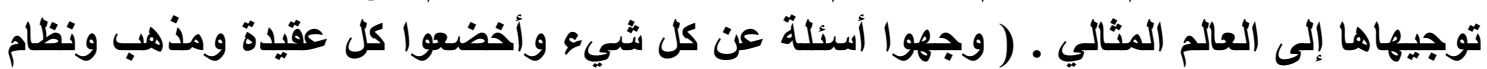

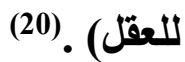

يعد القرن الخامس للميلاد من أهم عصور الحرية وعصور تطور الفكر وممارسة الديموقراطية

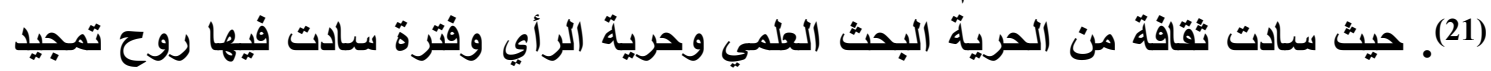

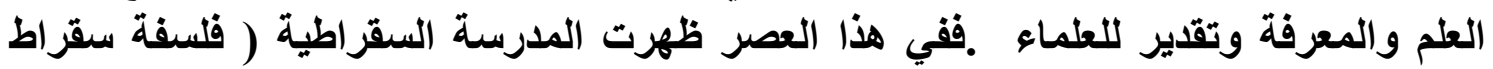

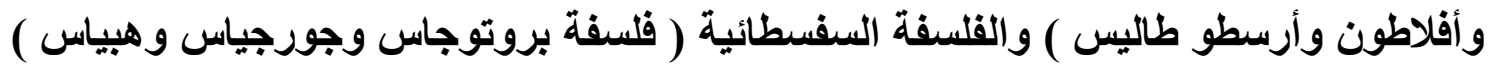

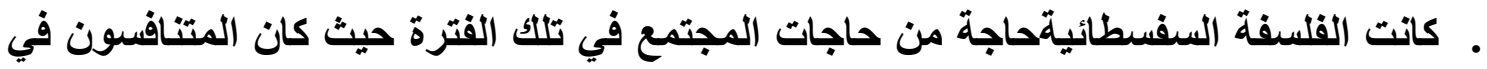

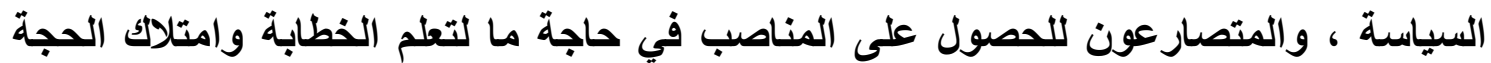

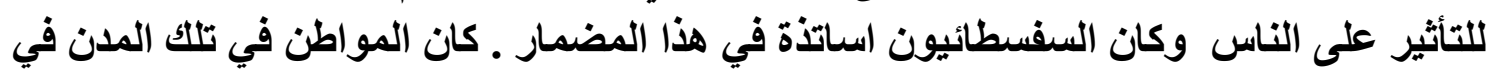

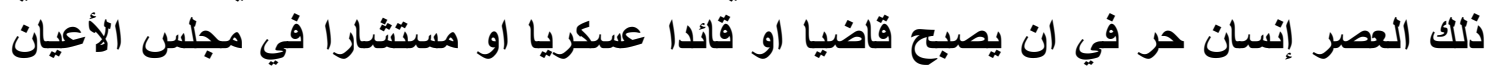

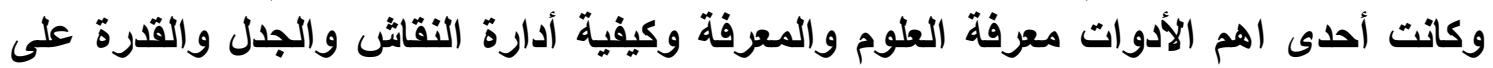

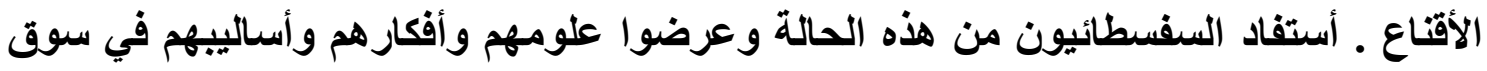

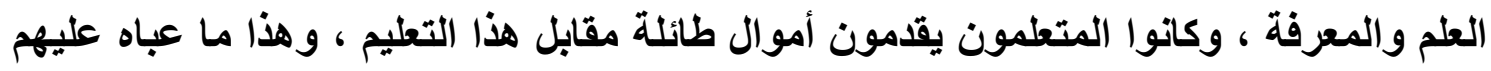

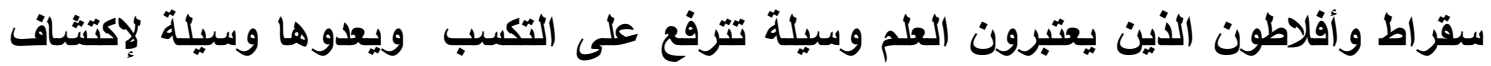




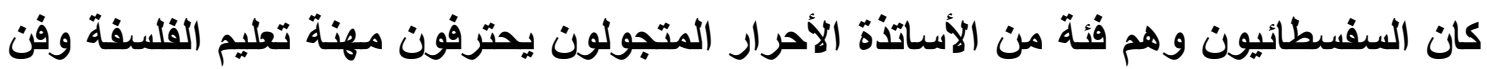

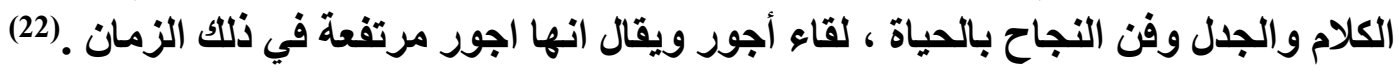
أستفاد السفسطائيون من روح التسامح التي سادت في أثينا من حرية للفكر وتقبل للرأي الأخر

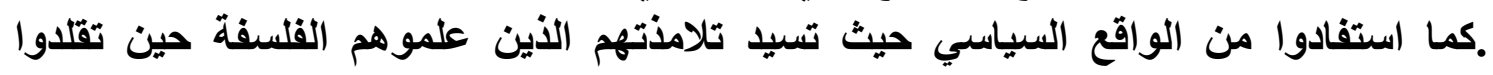

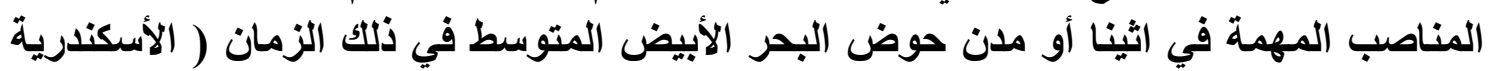

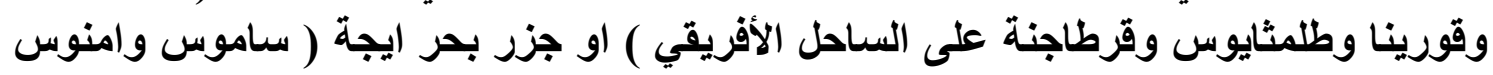

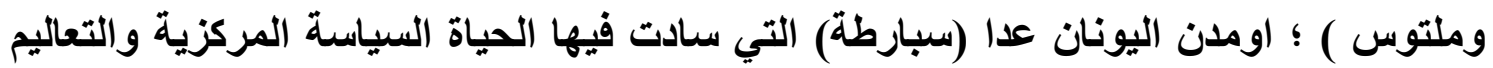

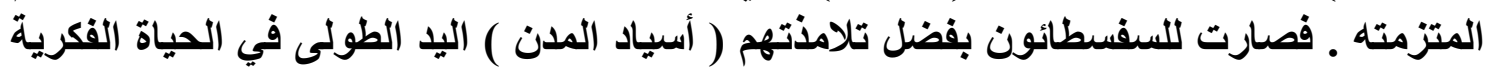

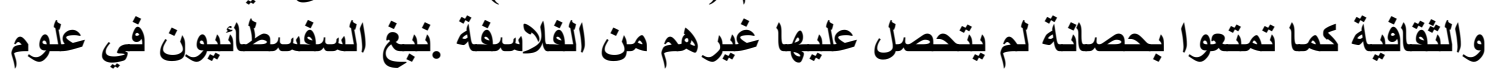

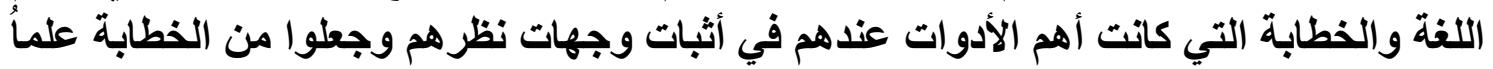

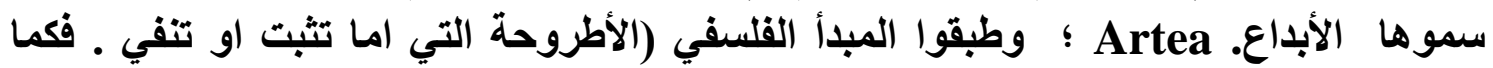

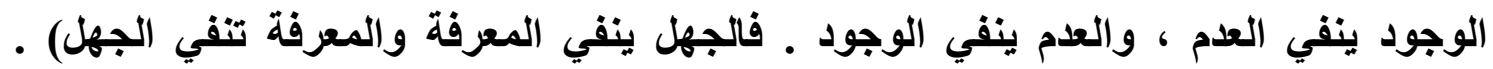

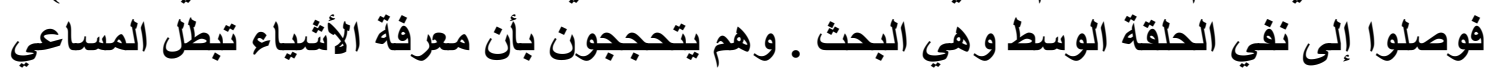

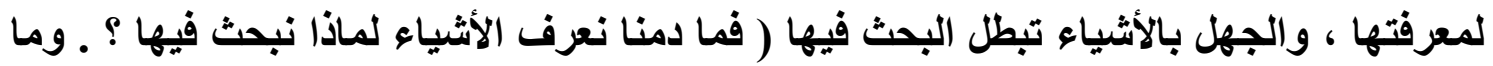

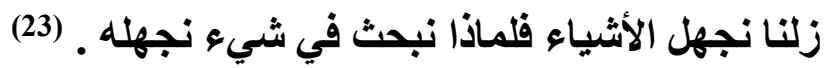

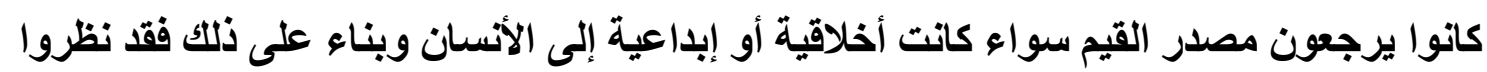

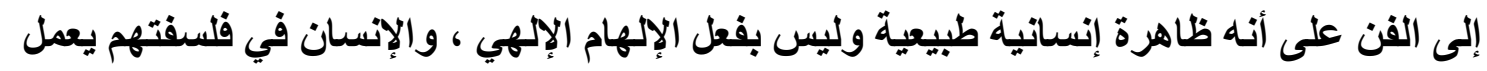

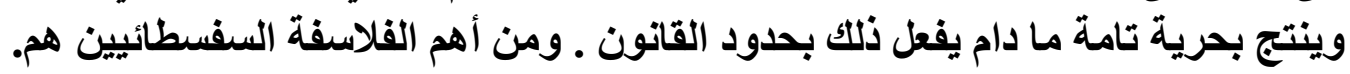

بروتاجوراس

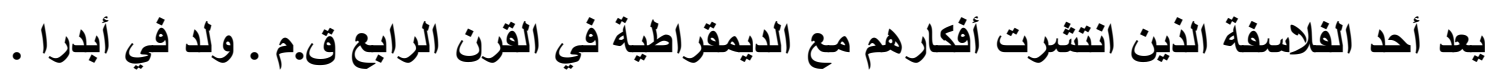

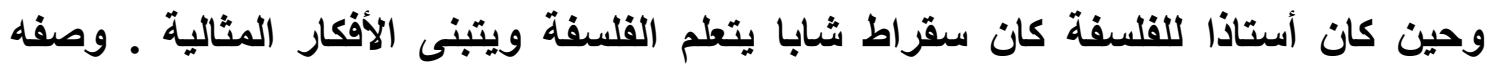

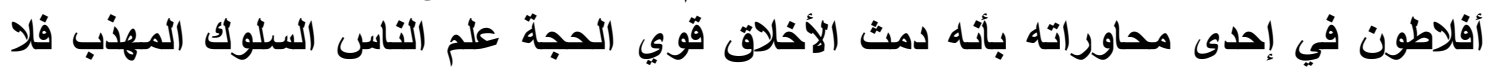

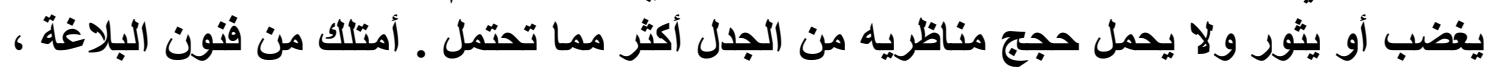

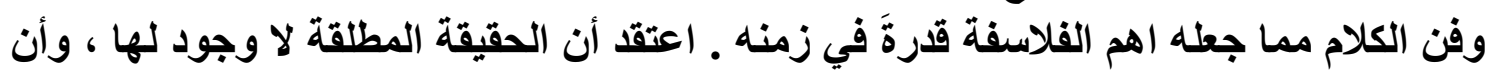

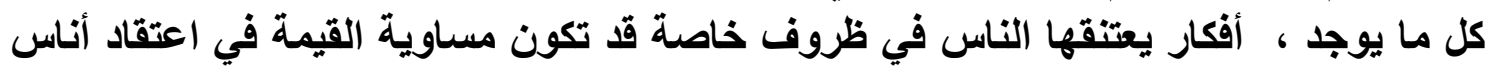

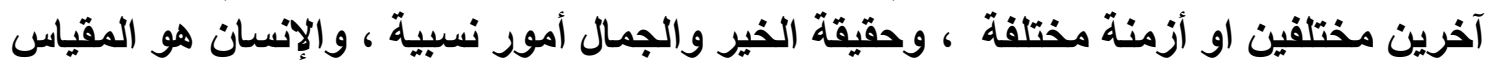

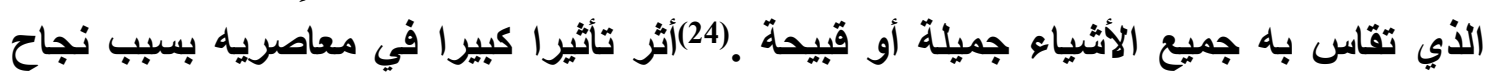

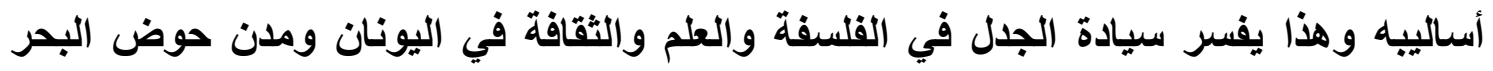

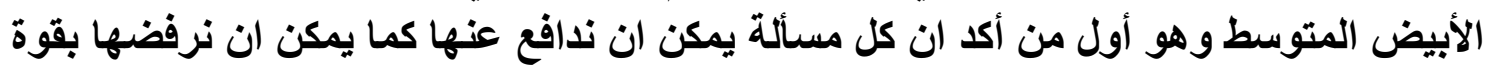


الحجة .25)تتميز فلسفته بتأكيد نسبيّة القيم ، إذ أن القيم تتغير حسب تقبل الإنسان لها أو رفضه لها ـ وهو يعتبر أن الإنسان مقياس كل شيء. أعتقّد أن مفاهيم الإنسان عن الحق والعدالة والجمال غير ثابتة بل هي متغيرة ولا ترجع إلى الى التى

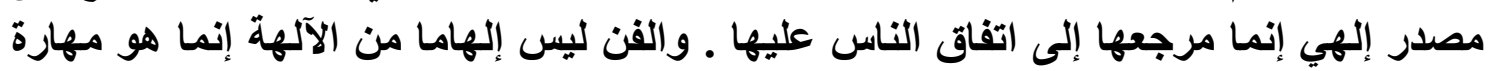

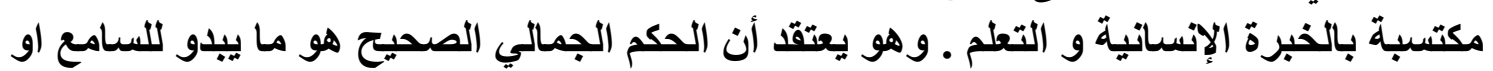

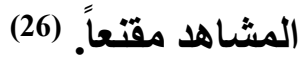

جورجياس

ولا سنة 483 ق.م في (ليونتي)، قضى معظم حياته خارج أثينا ، حتى أرسلته مدينته سفيرا لها

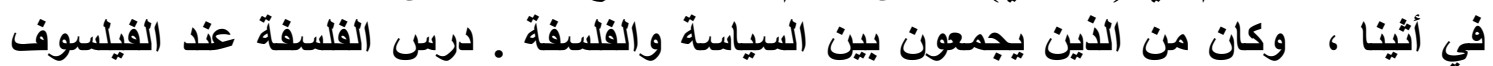

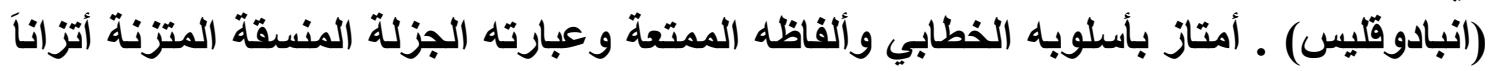

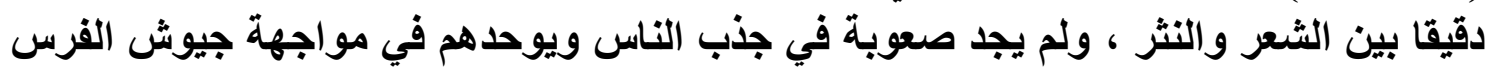

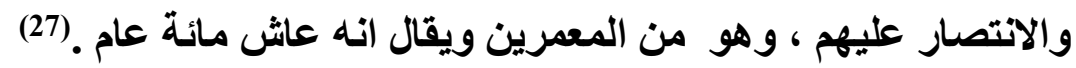
أعتقد هذا الفيلسوف أن الجمال مستقل عن الحقيقة ، بل أن الوهم يغديه ويزيد من جماله ،

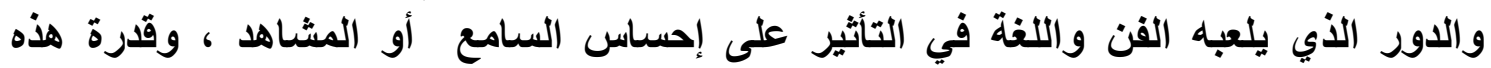
الأحاسيس على بعث الأوهام التي تسلب الإنسان أرادته وتجعله مرتبطاً بسحر الفن أو الكلام . أتخذ من أسطورة هيلينا التي انجذبت إلى باريس وتركت أهلها وهربت معه إلى طروادة أعداء

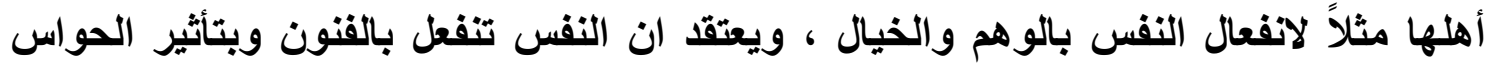

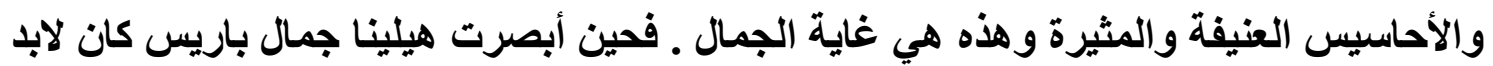

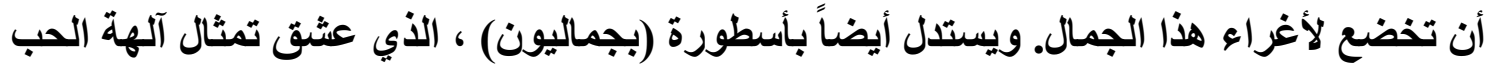

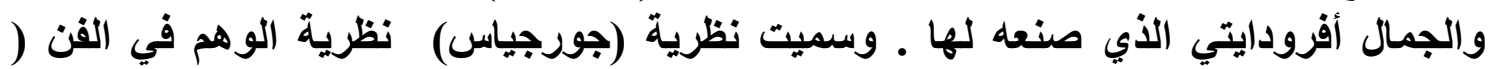
ويقصد بالوهم هنا التأثير العاطفي على السامع والمشاهد ـ والتي سعت إلى ارتباط الفن بالنشوة

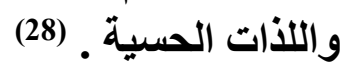

عارض أفلاطون (صاحب النظرية المثالية في الفن ) هذه النظرية ، وعدها لا توجه الجمهور إلى الى الجي الخير بل توجهه إلى اللأة ، ولما كان هذا الفن لا ينطوي على الحقيقة ولا الخير ولا الجمال فأنها خيال ومحاكاة مزيفة.

سقراط عاش (سقراط) من أجل الفكر ومات من أجل فكرة ـ لم يعمل قط ولم يهتم بالذي سيأتي كان همه

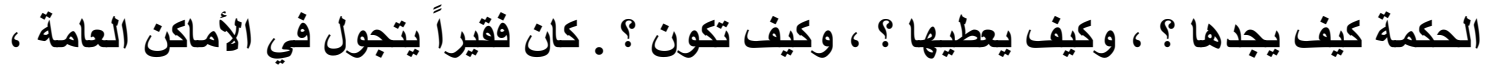




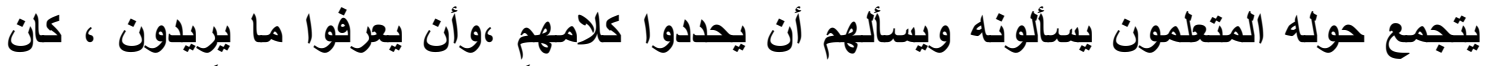

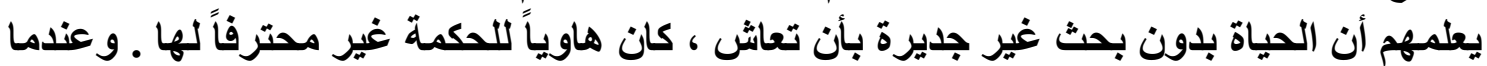

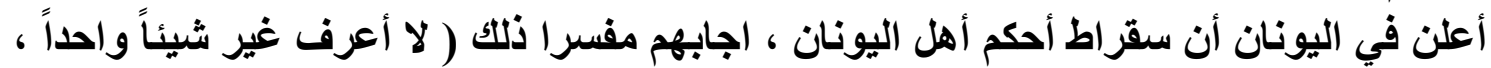

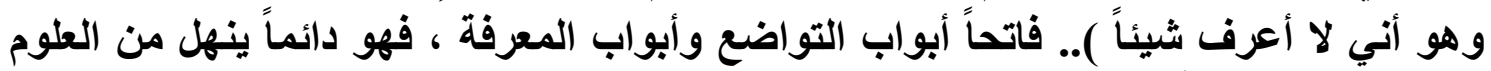

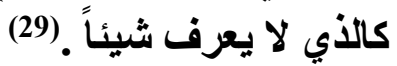

تبأ الفلسفة عنده بتعلم الإنسان الشكك و تلخصت فلسفته بعبارة ( أعرف نفسك ) ـ ـ كانت الفلسفة

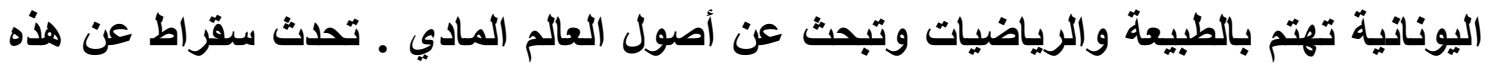

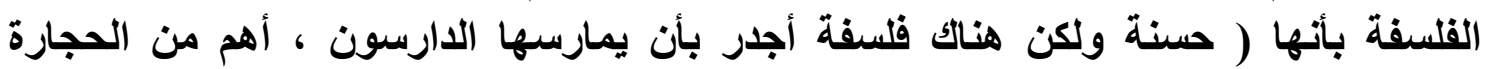

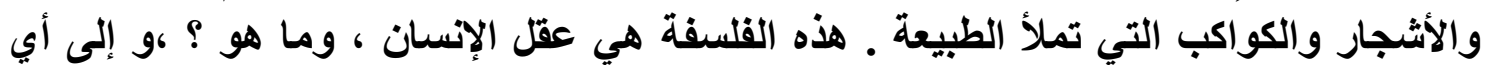

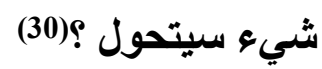

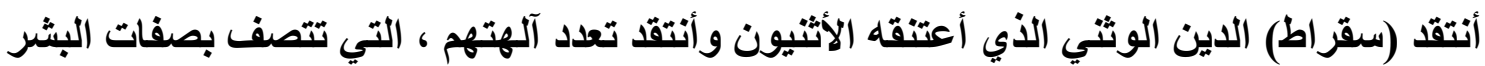

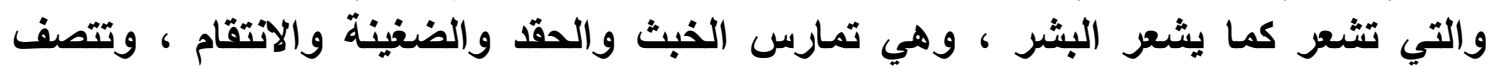

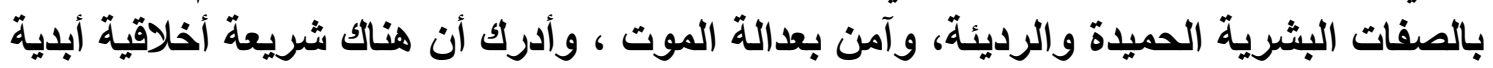

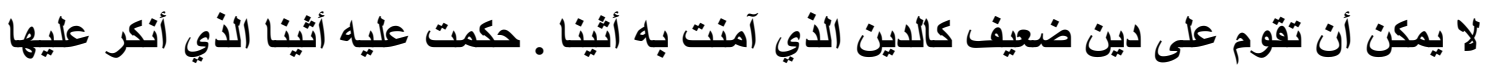

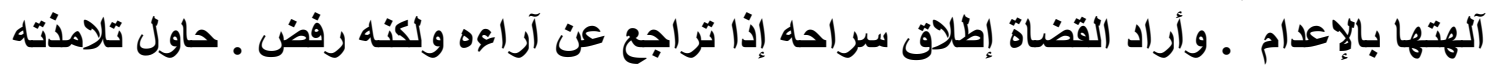

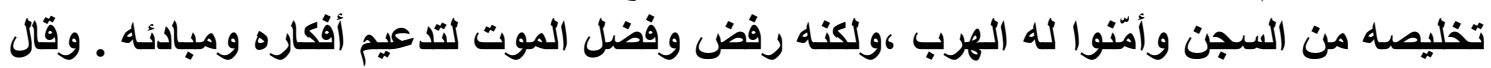

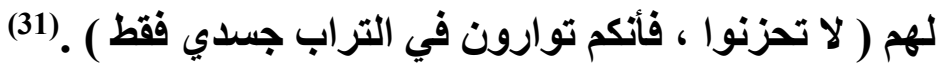

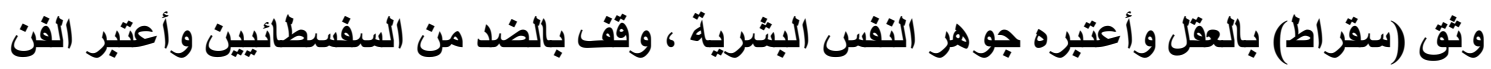

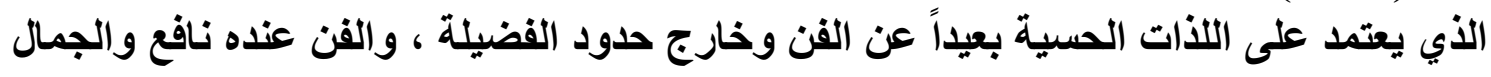
يحقق فائدة وله غايات أخلاقية.

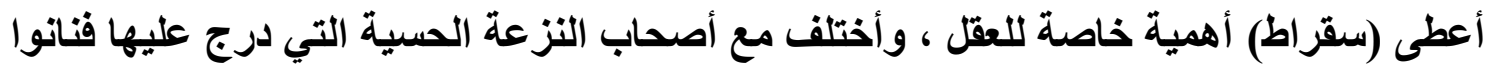

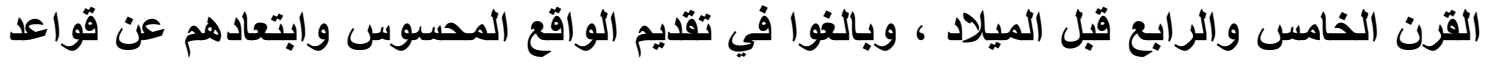

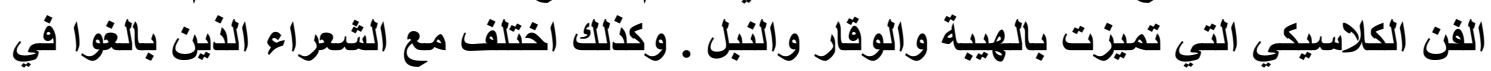

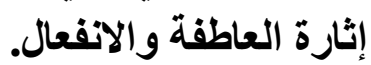

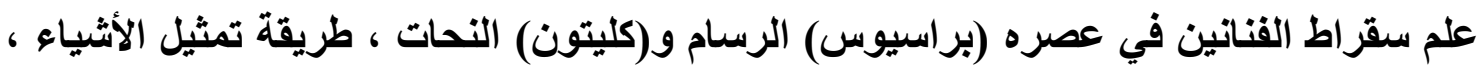

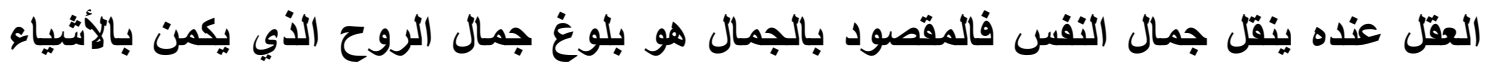

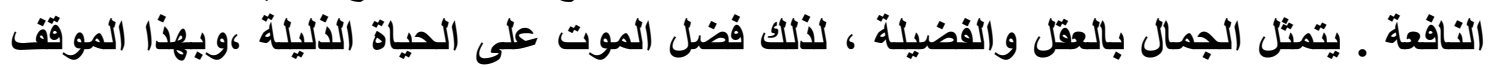

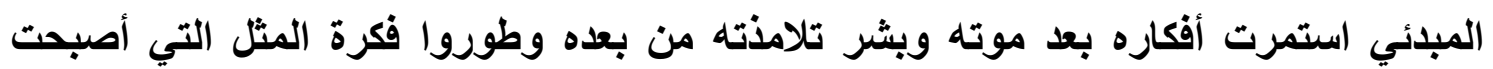

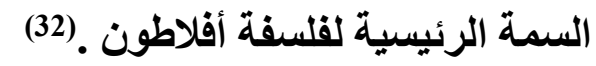


تعتبر محاورات أفلاطون وكتابات (زينوفون) هما المصدران الذي يُعتمد عليهما في نقل حياة

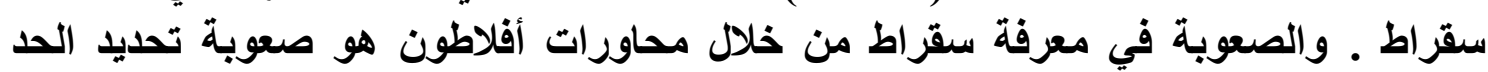
الفاصل بين إرادة سقراط وإرادة أفلاطون.

لاحظ (سقراط) إن لكل عضو في أعضاء الكائنات فائدة أو غاية فالعيون خلقت من اجل الروئية و

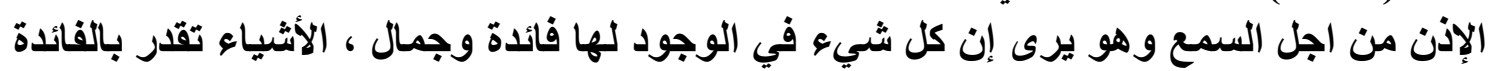
التي تعود بها على الأنسان .

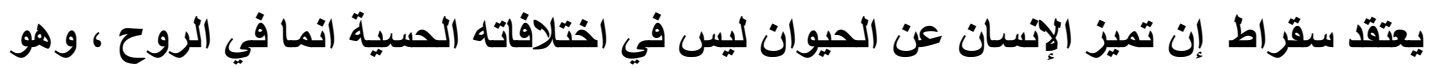

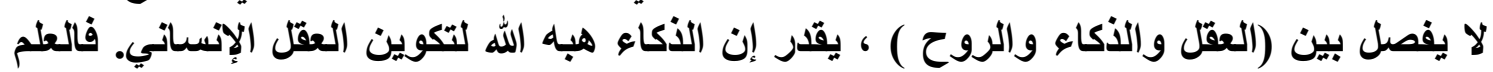

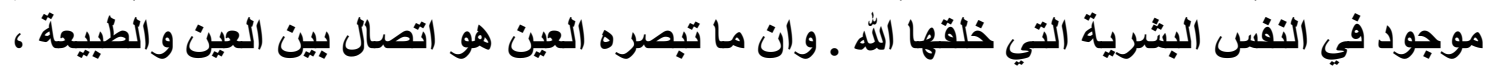

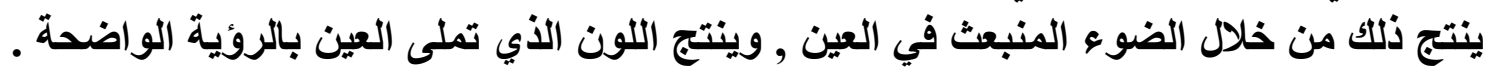

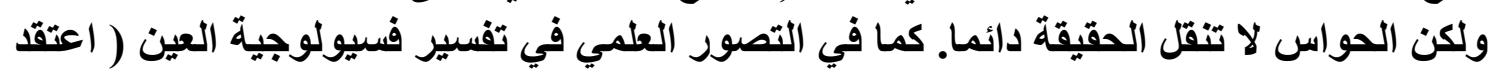

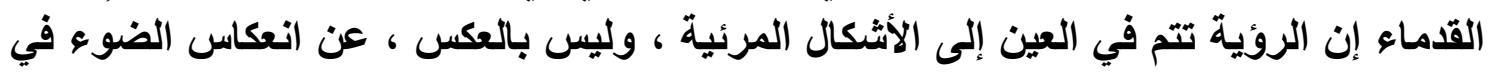

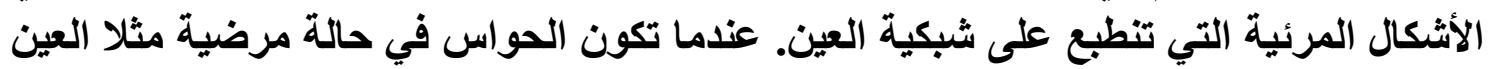

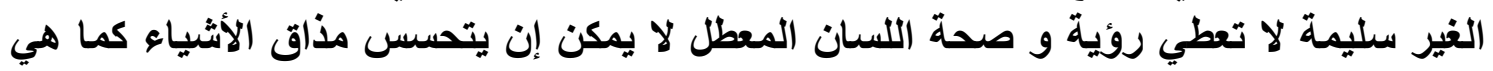

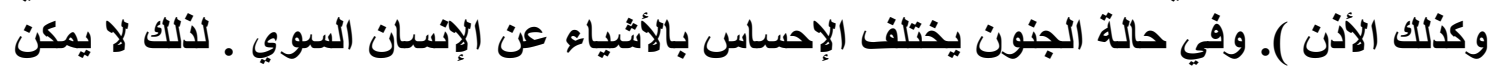

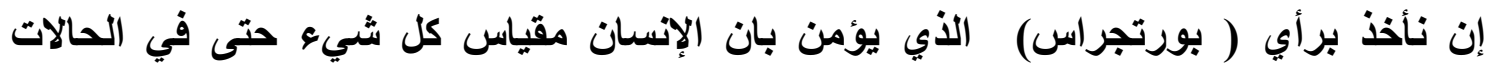

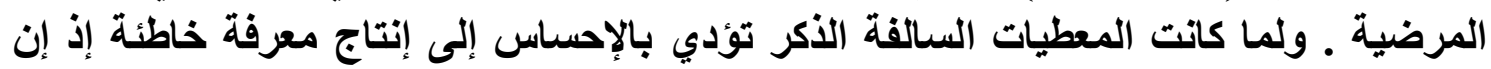

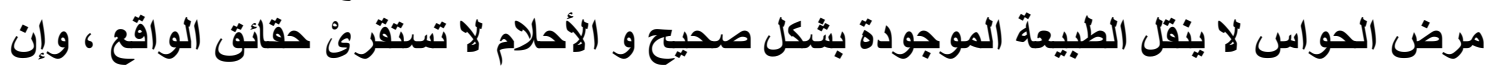
العلم و الإحساس لا يمكن إن يكون شي واحد كما يدعى السفسطائين.ويعتقد ان الأنئ الأفكار

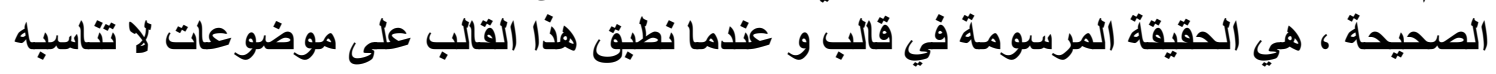

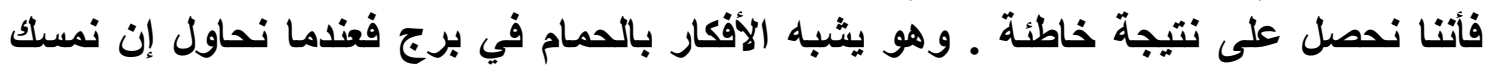
بأحدها فقد يحدث إن تمسك بإحدى غير تثلك التي ترغبها وهذا ما يقابله الأبل الأفكار الخاطئة.

أفّاطون

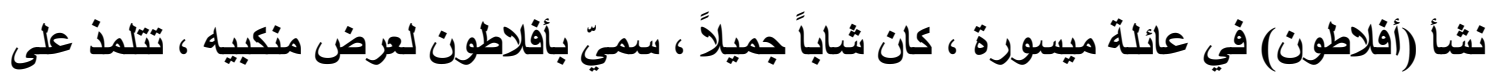

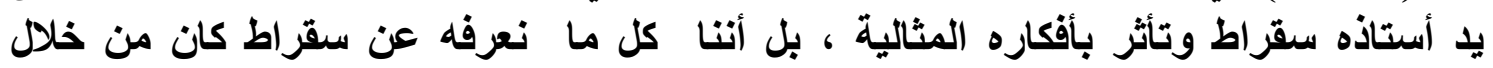
محاورات أفلاطون القلسفية.

دخل أفلاطون رياضة القلسفة تحت رعاية (سقراط) وإرشاده ، وأنتقل من مرحلة النقاش إلى

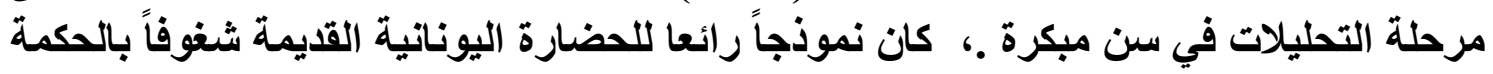


وبمعمه (سقراط) ، معتدا بنفسه فخوراً بحضارته إذ يقول (أشكر الله الأي خلقي يونانياً لا

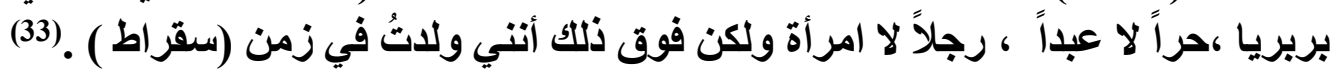
كان في الثامنة والعثرين من عمره عند موت( سقراط) ، وأصبحت حياته محفوفة بالمخاطر

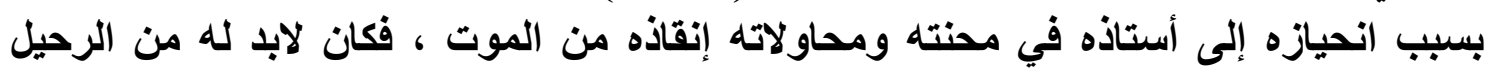

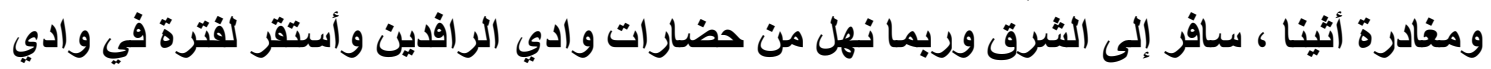

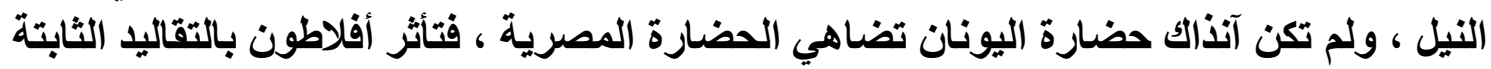

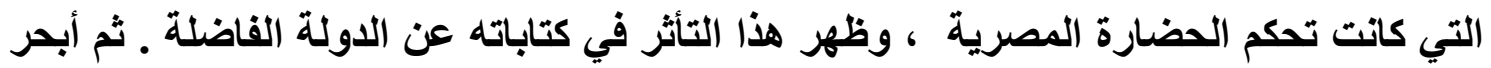

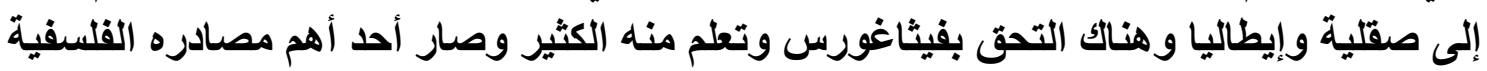

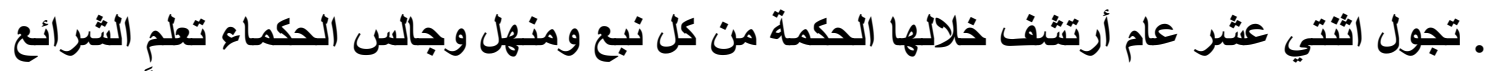
والقوانين . عاد إلى أثثينا في الأربعين من عمره وقد نضجت أفيف أفكاره وأكتسب معرفة وفي وفناً ، فالأول مرة يعيش الفيلسوف والثاعر معاً.

أبتدع أسلوب المحاورات وسيلة لنقل أفكاره ، ويمكن القول أن هذه المحاورات إحدى كنوز

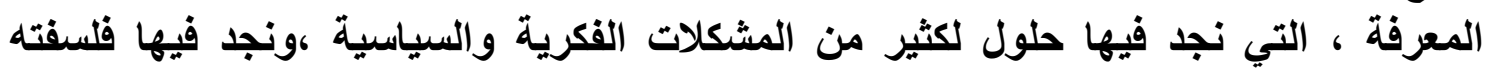
الأخلاقية والأدبية و النفساتية ونظريته في الفن.

تعتمد المحاورة على ثلاثة أطراف ، المحاور الأول ودائما ما يكون بطله الرئيسي المعبر عن

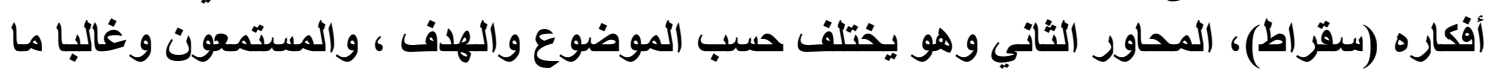
يكونوا تلامذة سقراط ـ بعض محاوراته تعد تراجيدية مثل( فيدرون) ، بعضها تعد كوميدية مثل فئل

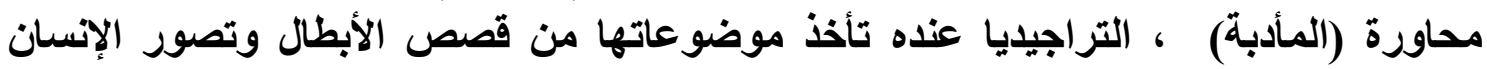

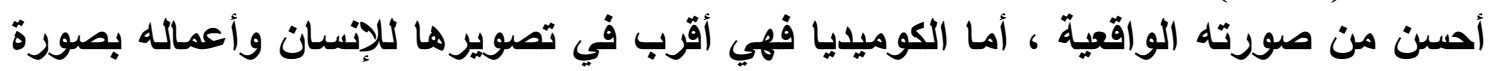

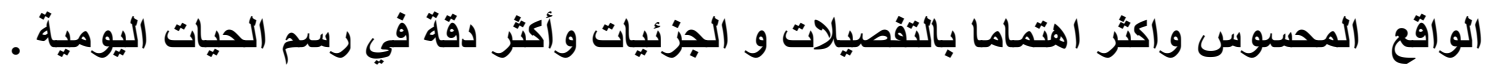

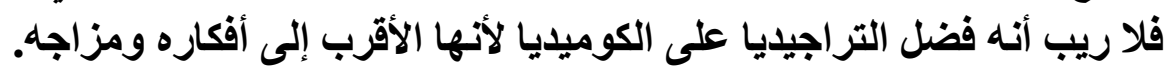

يعرف (أفلاطون) القلسفة بأنها الحكمة ويعرفها أيضا بالحقيقة وكل ما نراه مظهر لأصل ثابت (نموذج) ، وللوصول الحقيقة يقسم الموجودات مثال وظاهر فالمحسوسات مظاهر مثلك:

1

2.

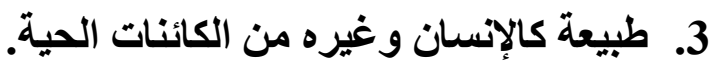

يعتقد ان العالم خلق من مادة غير مستقرة التي كاتت في حالة غير منتظمة و فوضى غير خاضعة

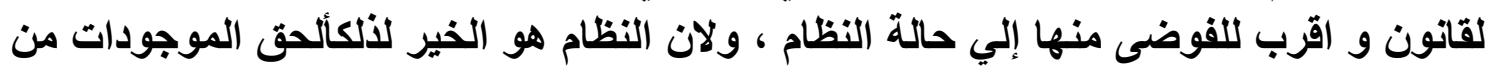

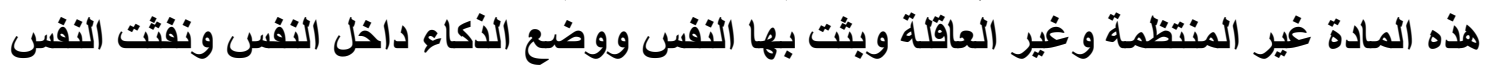




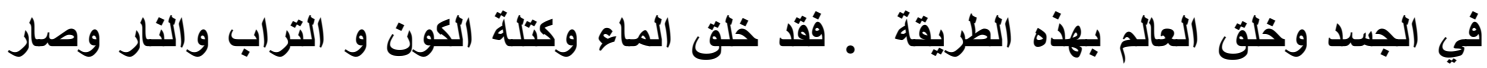

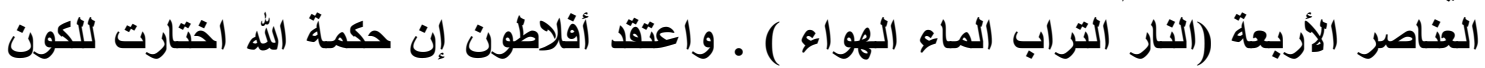
الشكل الكروي أو الدائري الذي تتساوي فيه الأبعاد. بين المحيط المركزي من جميع الجهات.

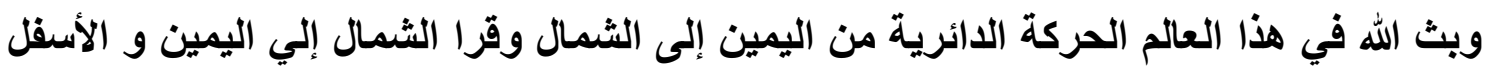

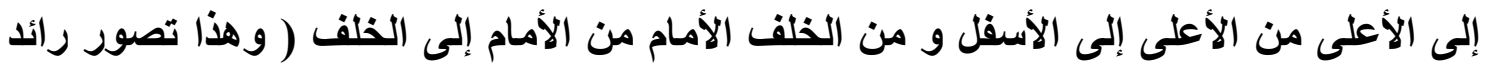
ومتقدم لكروية الارض. مئ الأل

واعتقد أفلاطون إن خلق العالم قد اقترن بخلق السماء الموصوفة بالخلود ، وهو ما نعرفه بالزمن

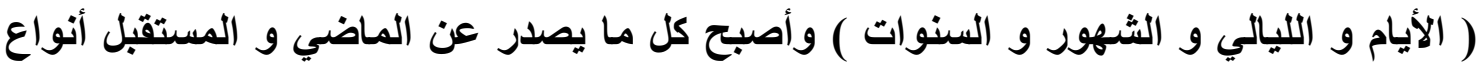
صادره عن الزمن وقد صنفه كان ويكون ، والزمن ( Temps ) والكون نشاء واحدة ومن اجل ونل

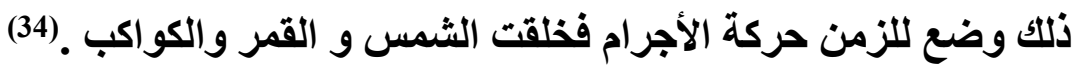

يمكن التعرف على نظرية أفلاطون في الجمال من خلال ثلاثية تفسيره للسلوك الإنساني فالسلوك

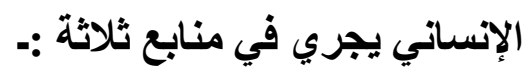

1. الرغبة ـ والثهوة ، مكانها في الأسود ، وهي خزان يتفجر حيوية وخصوصاً في الناحية 2. العاطفة ، والروح . والطموح والشجاعة . مكانها القلب في قوة ومسرى الام ، وهي

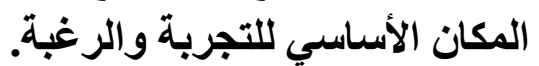

3. المعرفة ، والقكر والأكاء والعقل , مكانها في الرأس وهي عين الرغية الرغبة وبصرها ، وهي

$$
\text { مرشد الزوح وهاديها }
$$

يتركز مفهوم الجمال عند (أفلاطون) في محاورة المأدبة والتي يمكن من خلالها استخلاص فكرة

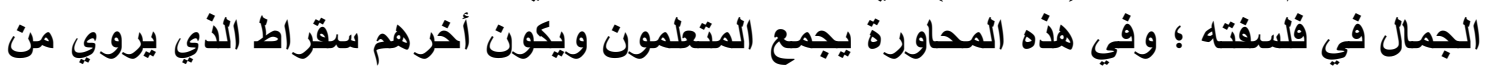
خلال النقاش قصة الفتاة ( ديوتيم)- سقراط ينوب عن أفلاطون في جميع محاوراته ، ويمثل الحقيقة التي يعتقدها(أفلاطون)- تتلخص فكرة الفناة (الحب والجمال عنده كالآتي :-

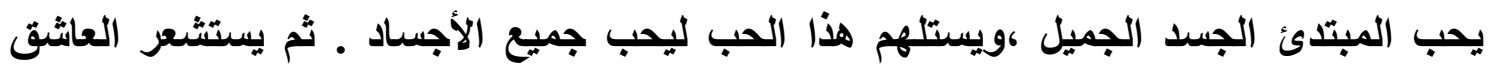

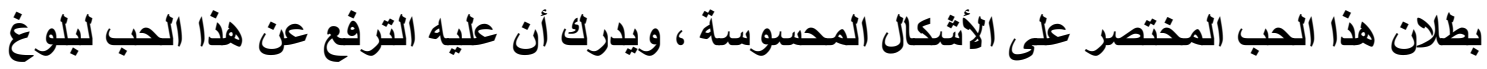

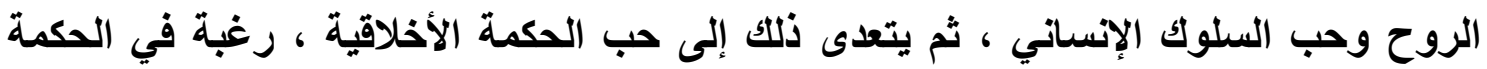

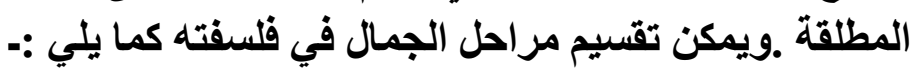

$$
\begin{aligned}
& \text { 1. حب الأثكال المحسوسة. } \\
& \text { 2. حب النفوس. } \\
& \text { 3. اكتساب العلم. }
\end{aligned}
$$


وبعبارة أخري يمكن تقسيم فكرة الجمال كما يلي ، الحب الجسدي ، الحب الأخلاقي ، الحب

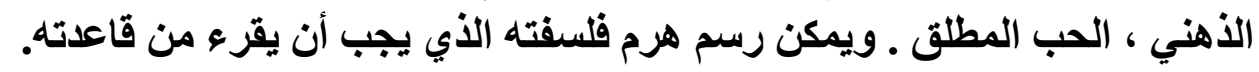

$$
\begin{aligned}
& \text { الخير } \\
& \text { الجمال ـ الحق } \\
& \text { الأفكـــار الكليــة } \\
& \text { الأفكـار الخـاصة و الكلية } \\
& \text { جوهر الحقيـبـة الحسـية } \\
& \text { النفوس ـ الأفعال ـ الأجسام الأولي ـ }
\end{aligned}
$$

ينبغي على الفن عند (أفلاطون) أن يبتعد عن البيان و السفسطة ،وخداع العين وأن يبتعد عن

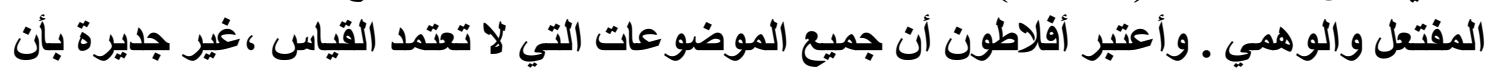

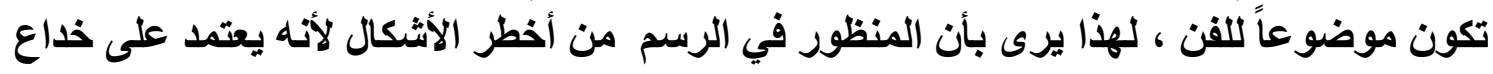
البصر ، فالفن عنده أينما كان يحدد بالقياس و الانسجام ويعتمد على القياس الرياضي. (35) رفض (أفلاطون) الفن القائم على إثارة الحواس ،وطالب بفن غايته المحافظة على النسب

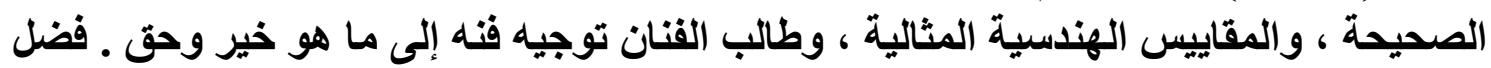

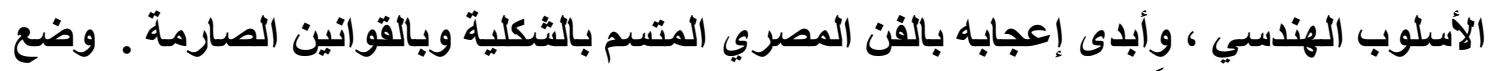

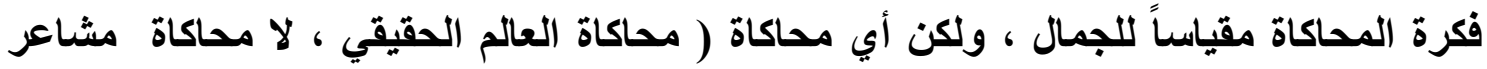

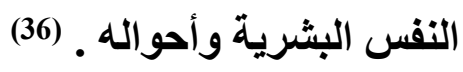

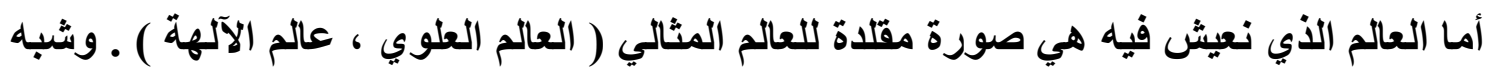

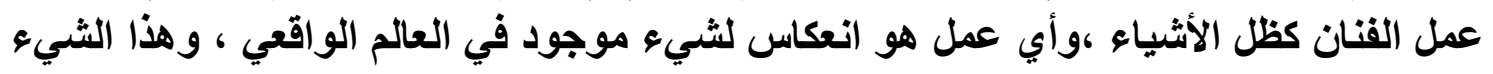

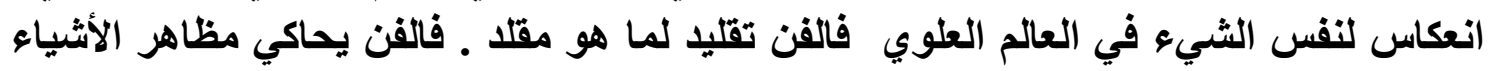

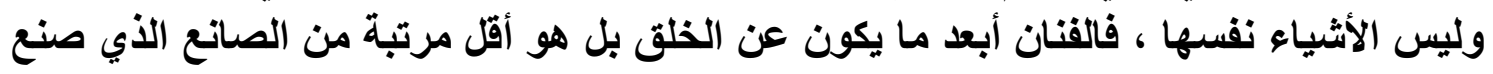
الأشياء . ولير الانئ.

يحاسب (أفلاطون) الأعمال القنية على أساس ما فيها من معلومات ، ويفترض أنها تعين الإنسان

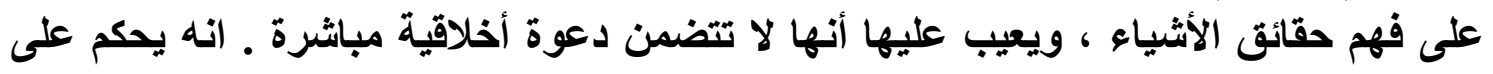

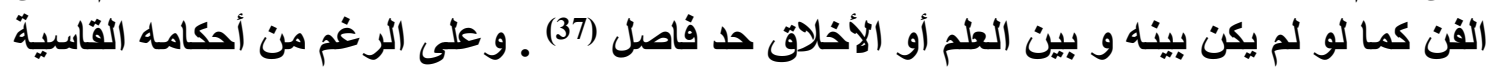

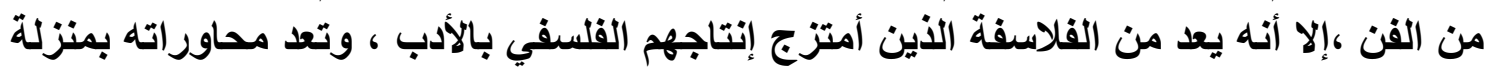

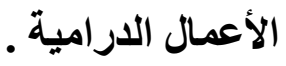


أرسطو طاليس

ولد(أرسطو طاليس) في مقدونيا التي تقع شمال أثينا عام 384 ق.م ، كان و الده صديقاً وطبيباً

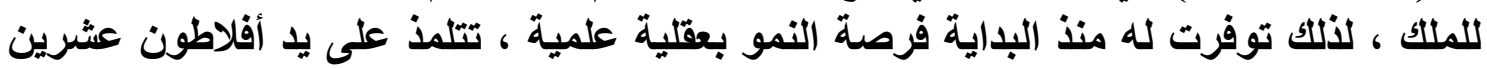

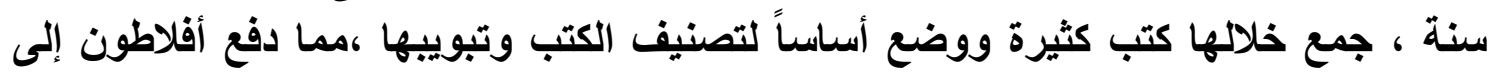
تسمية بيت أرسطو بيت القارئ. (38)

عهد إليه الملك فليب ملك مقدونيا بتثقيف (الإسكندر) ، مما يدل على شهرته حتى اختير ليكون

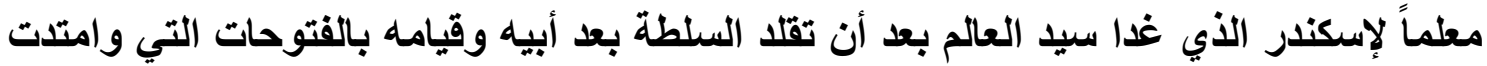

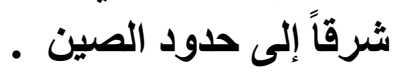

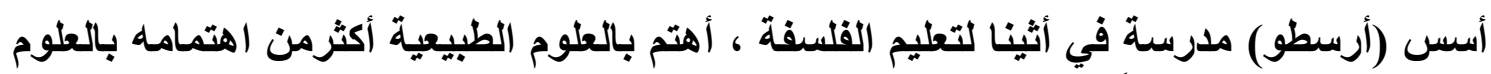

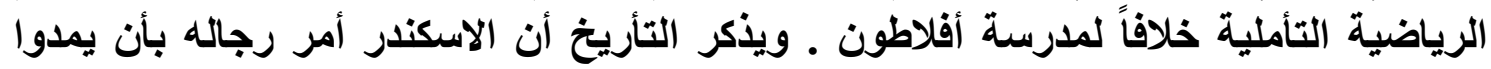

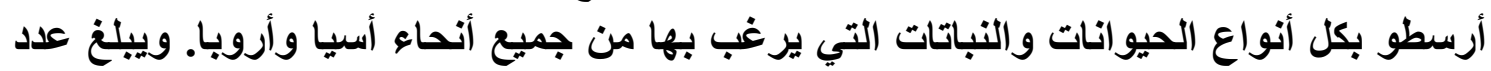

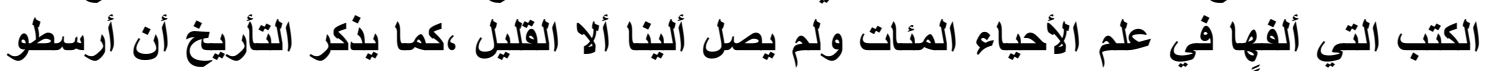

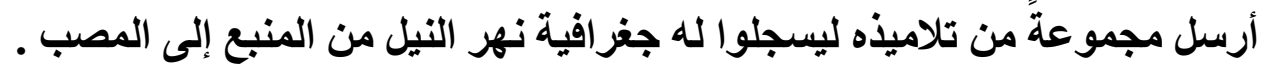

اختلف(أرسطو) عن أستاذه الأي كان يعتق إن الحقيقة لا تظهر من خلال الحواس بل من خلال الحال

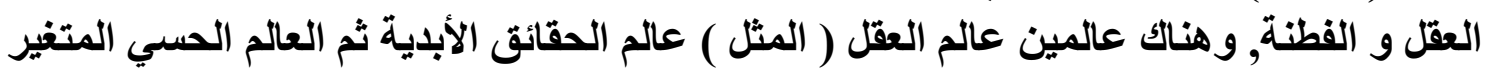

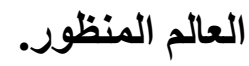

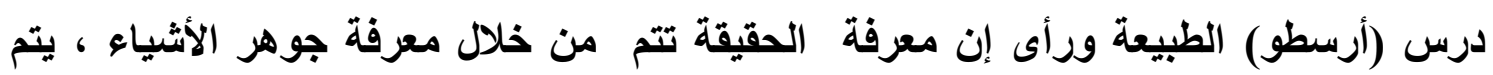

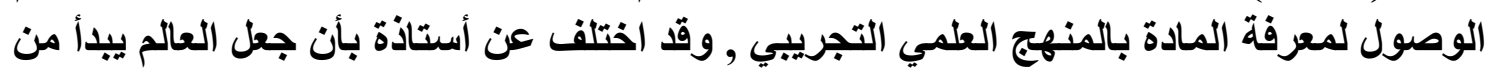
الجزئيات إلى الكليات

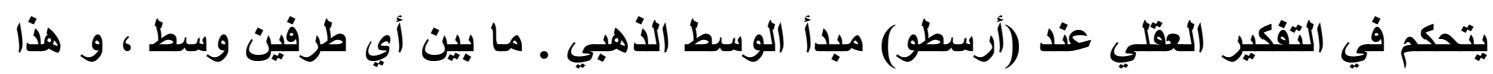

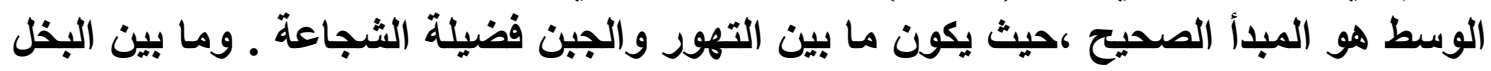

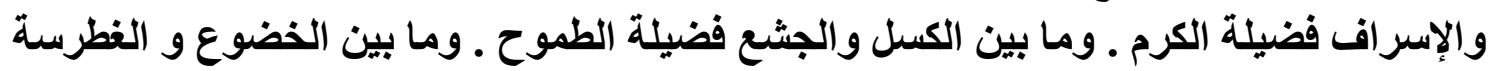

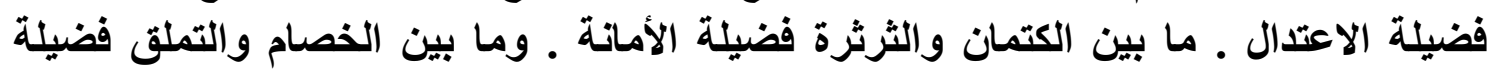

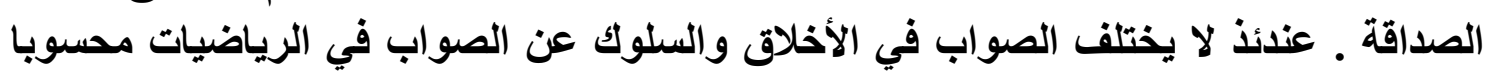

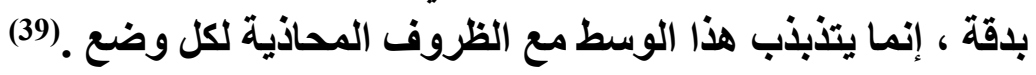

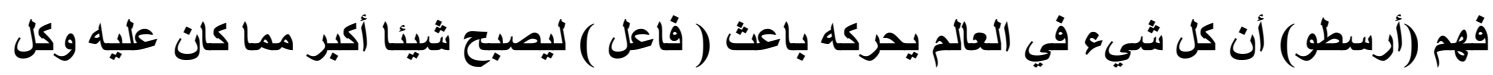

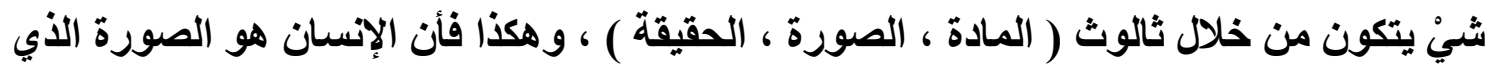

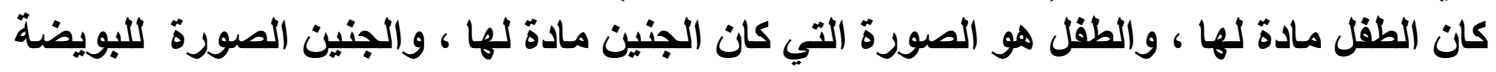




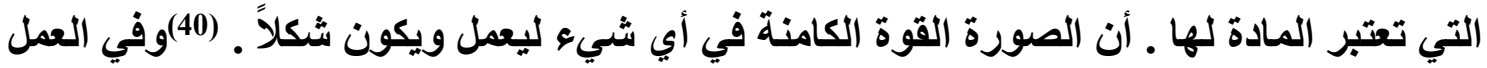

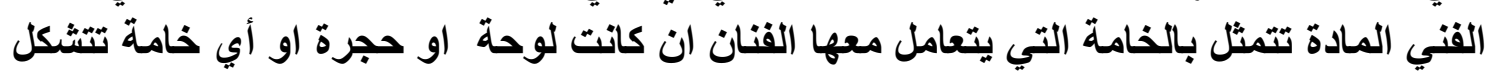

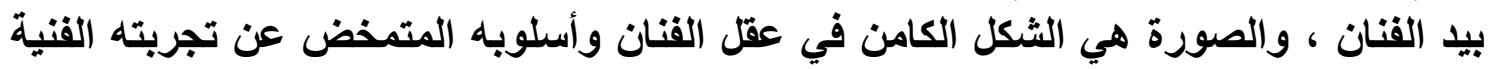

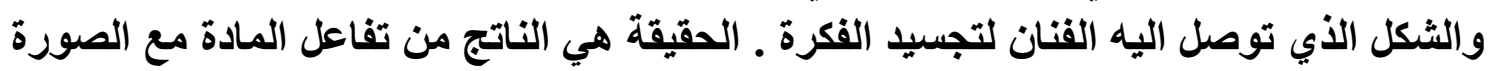

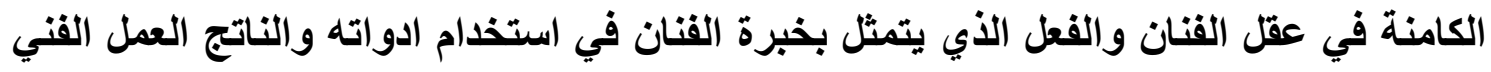
بصورته النهائية هي حقيقة عمل الفنان .

يعتمد الجمال عنده على اكتمال الثكل والمضمون ،ويتم ذللك بقانون التناسب والانسجام

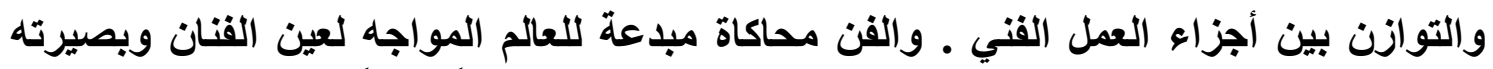

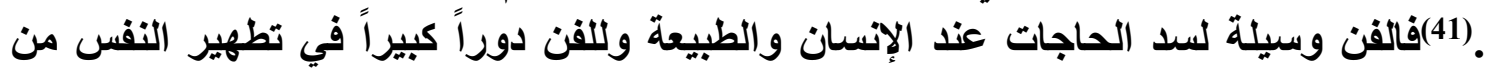

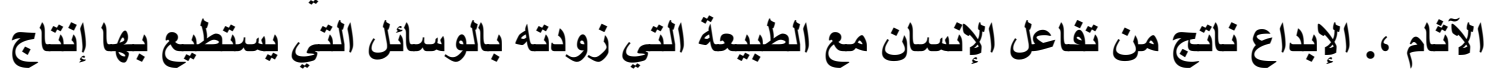

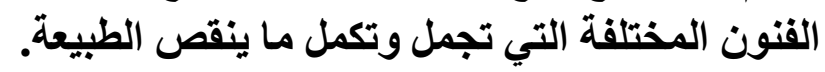

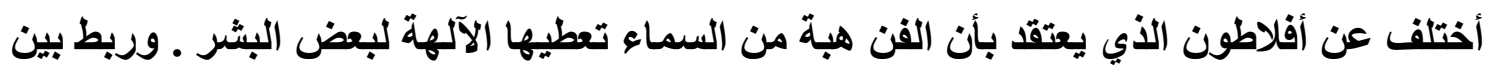

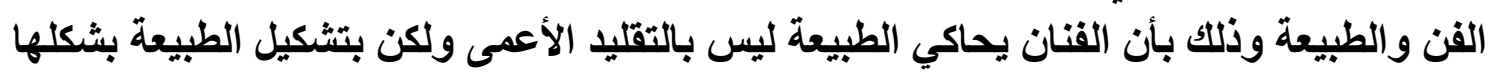

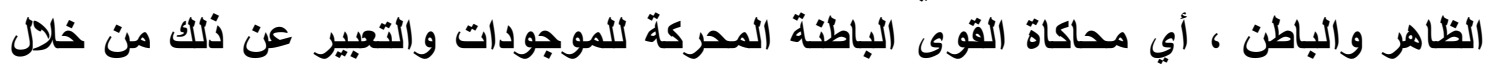

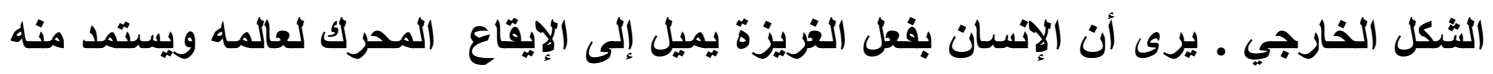

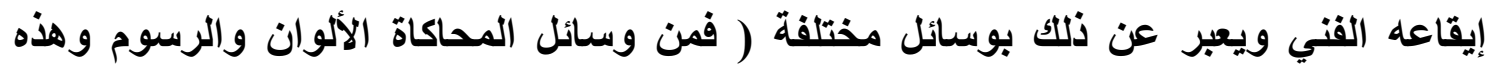

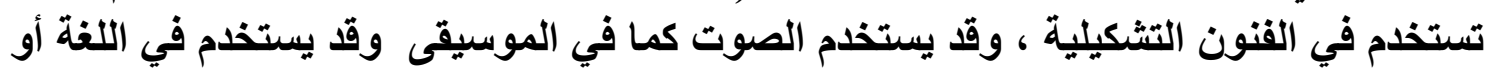

توافق النغم .

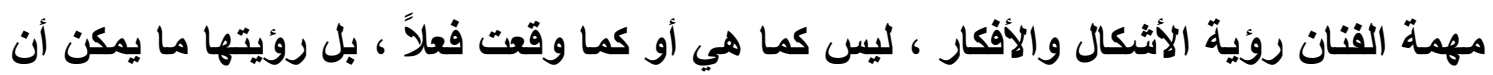

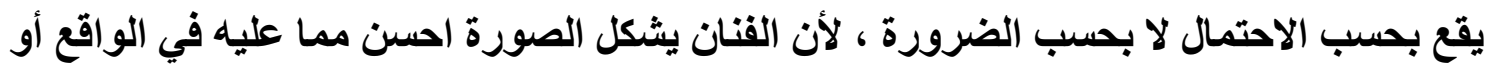

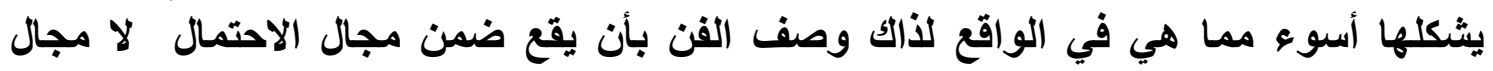
الضرورة .433)

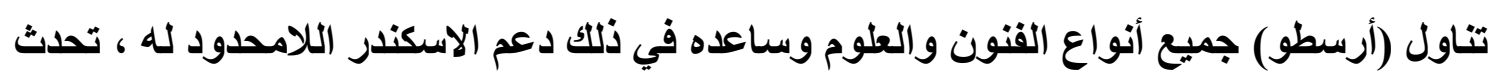

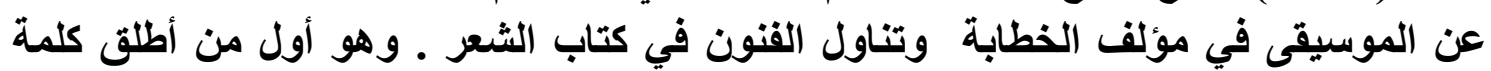

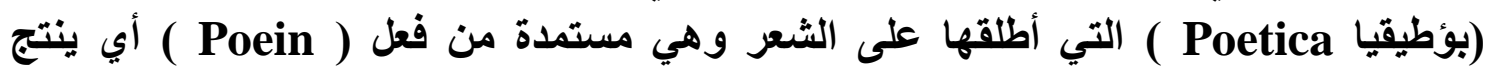

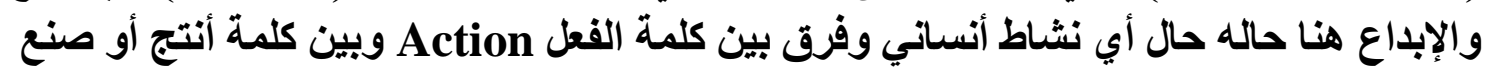
Make الفن فأن الفنان يضع صورة متخيلة بفعل الاحتمال . 
إذا كنا بإمكانتا أن نسمي موقف أفلاطون من الجمال بالمثالي فأنتا يمكن أن نسمي موقف (أر أرئ

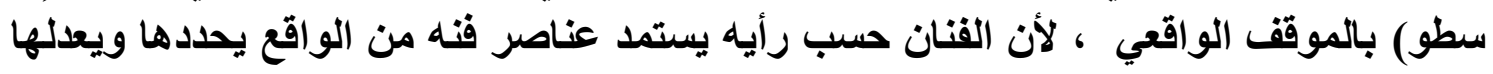

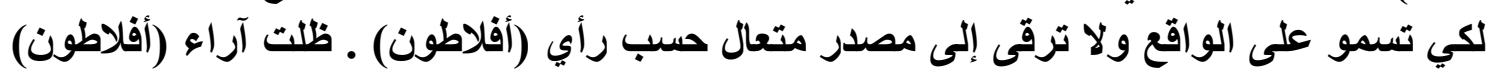

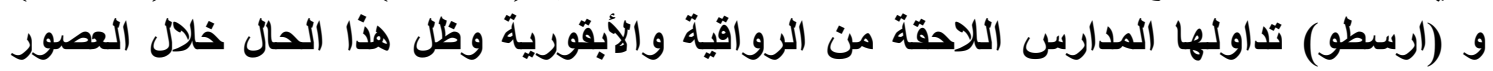

العصر الهلنستي

سميث القرون الثلاثة التالية لفتوحات (الاسكندر) المقدوني بالعصر الهلنستي إثـارة إلى تمازج

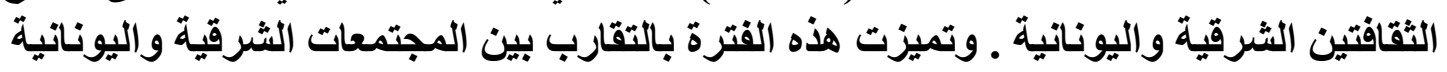

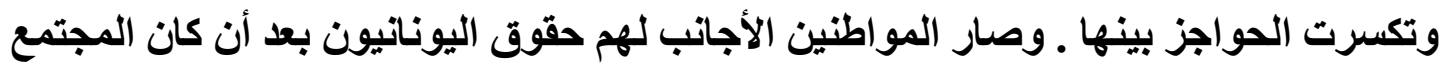

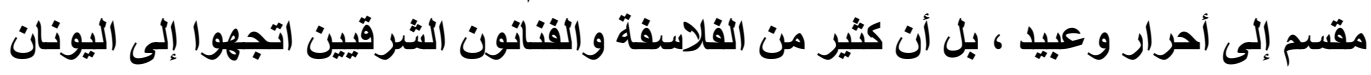

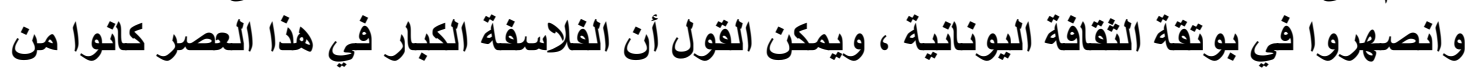

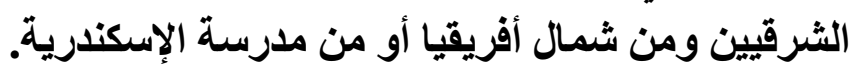

تميزت الثقافة و القنون اليونانية في هذا العصر بالتحرر من القواعد الكلاسيكية الراسخة وصار

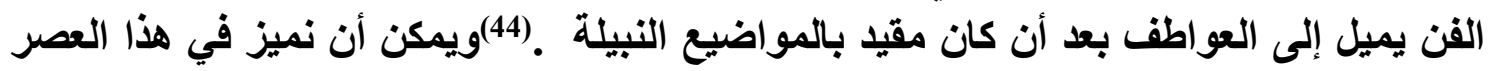

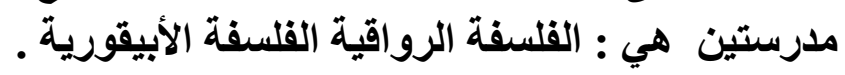

استمدت القلسفة الرواقية أسمها من الرواق حيث كان منشأها (زينون) 340 ق.م يعطي دروسه

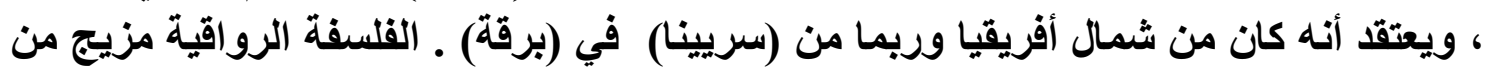

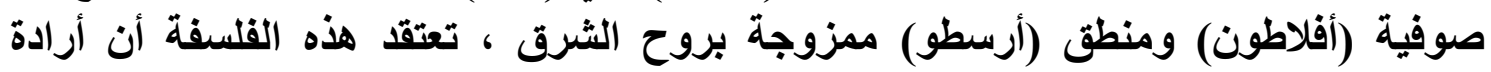

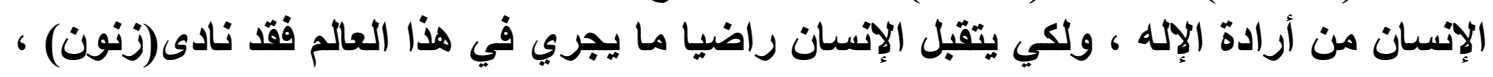

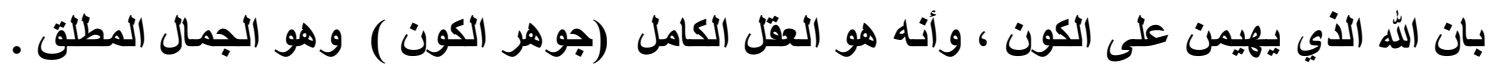
أن أراء الرواقيين دينية في جوهرها حتى وان اختلفت عن ديانة تعدد الآلهة التي كاتت سون سائدة

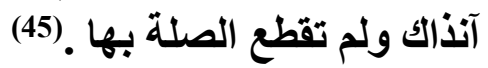

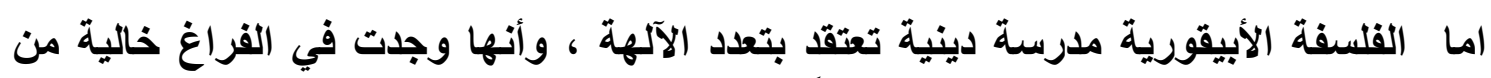

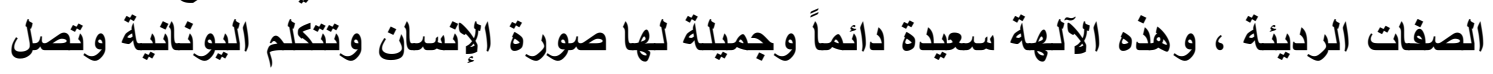

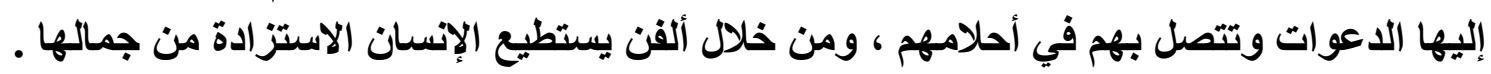
انتهى العصر الهلنستى بسقوط الثينا بيد الرومان.

عندما سيطرت روما على بلاد اليونان وجدت مدارس مختلفة تثقاسم الميدان القلسفي وبما أن

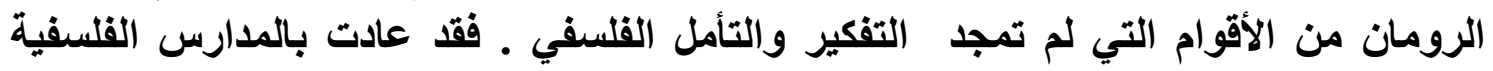
اليونانية مع جملة مغانمهم الحضارية ـ وقام الرومان باستنساخ الفنون اليونانية ، ويمكن القول 
بأن القنون والقلسفة الرومانية هي نسخة لقلسفة اليوناتية وأن مالت إلى التطبيق العملي

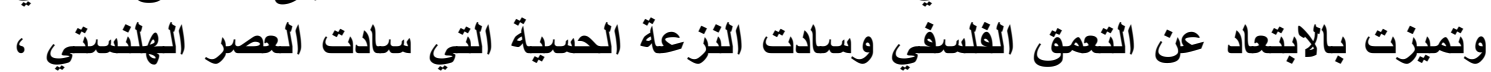

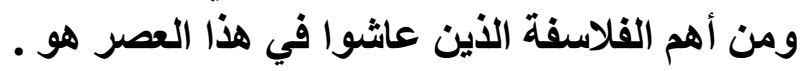

أفلوطين.

يعتقد (أفلوطين) أن الجمال هو أقرب شيئاً للنفس بل هو محبة النفس لأنه من طبيعتها وهو

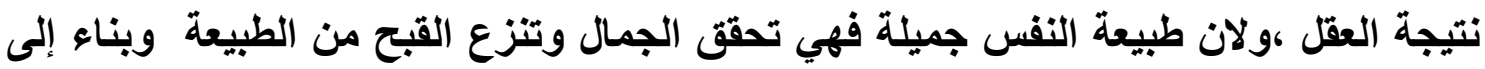

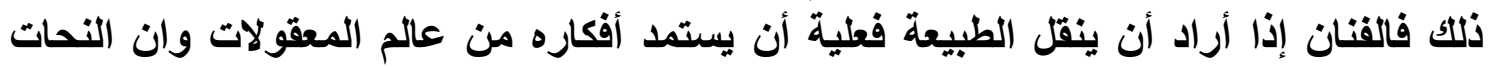

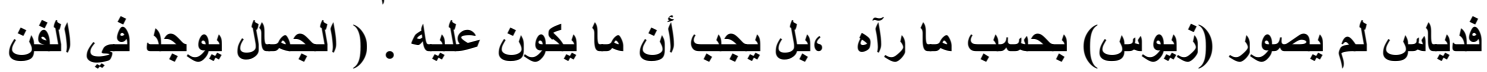

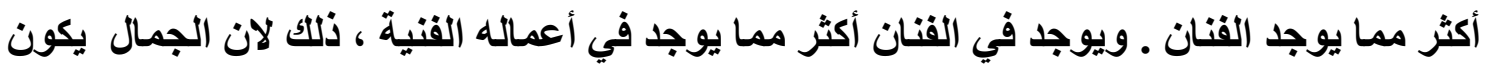

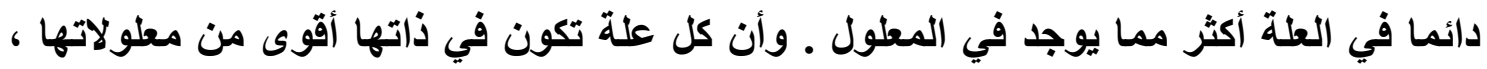

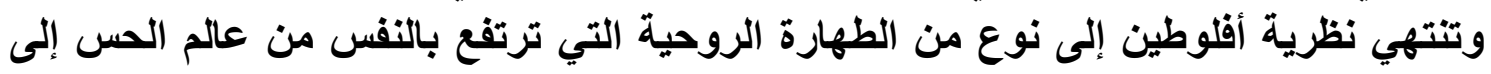

عالم الحقائق الروحية )

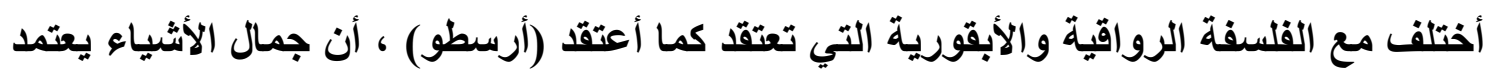

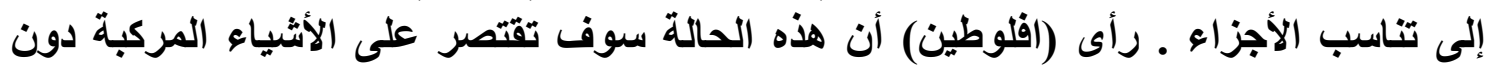

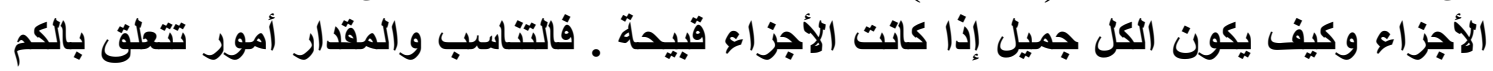

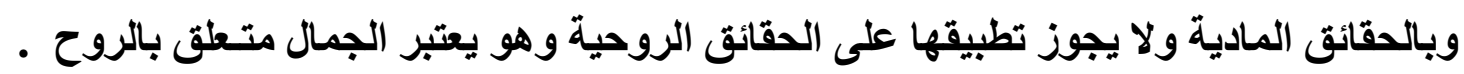

ينقسم العالم عند أفلوطين إلى عالمين : عالم المعقول و هو عالم الحقيقة ، و علم المحسوس و

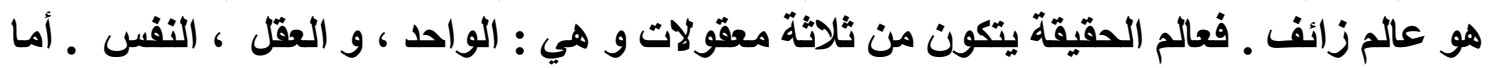

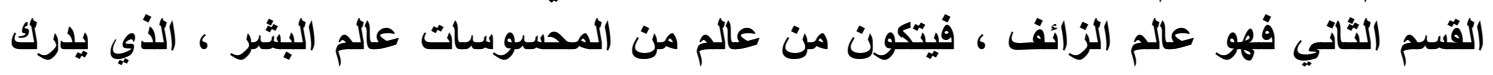

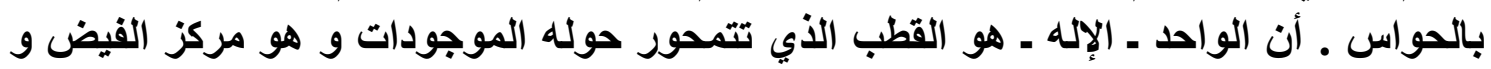

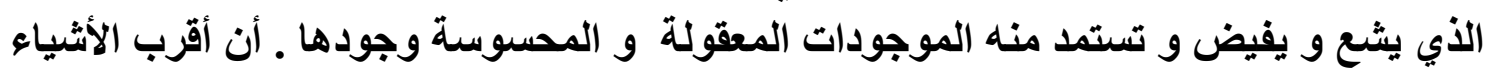
إلى الله و التي تفيض بضوء من الله ـ العقل - و هو أولى الدوائر حول المركز الفيض و و ثناني

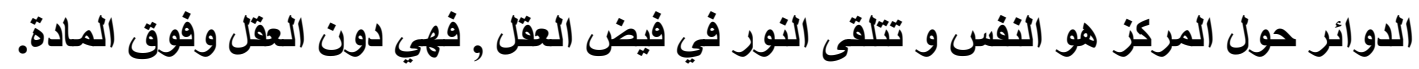
يفترق العقل عن الواحد من حيث أنه ذو موضع يمارس فعل التعقل و مما يؤدي إلى أنه بحاجه

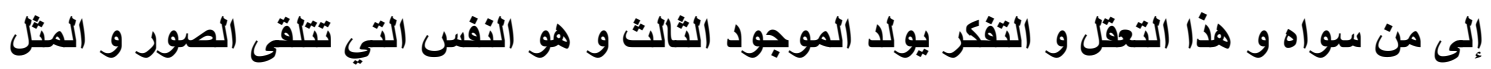

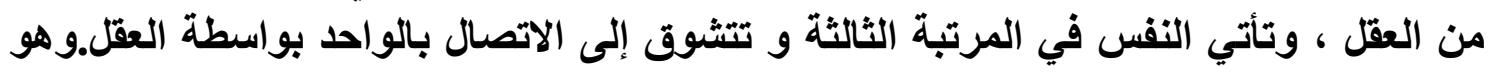

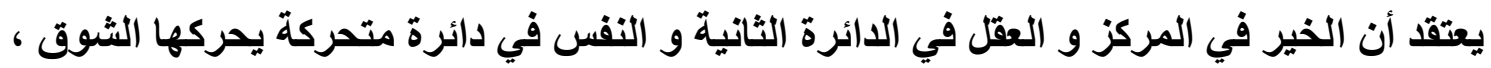
إذا أن العقل يمتلك الخير مباشرة و يفهمهـ. مميزات النحت اليوناني القديم . 
امتزجت عند الإغريق فكره عالم الآلهة العالم المثالي ، العالم الخالد عالم الجمال المطلق بعالم

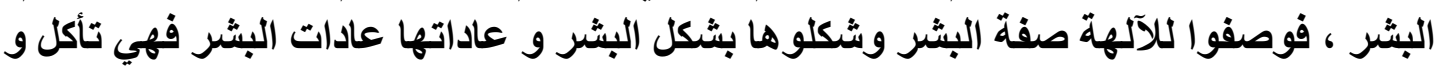
تشرب وتحب وتكره وتغار وتحارب وحتى حين حاول سقراط نفي هذه الفكرة وتعديل جمال الآلههة

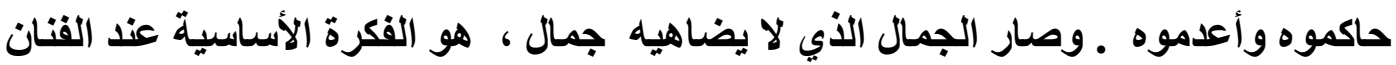

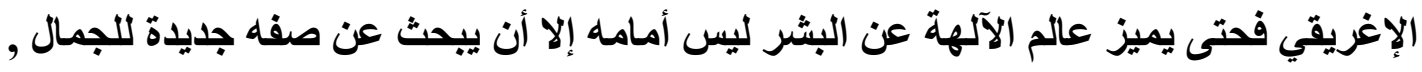
لاللك ابتكروا أسلوب نحت وجوه الآلهة خاليه من التعبير الإنساني وأضفى عليها طابع الإنه التبل

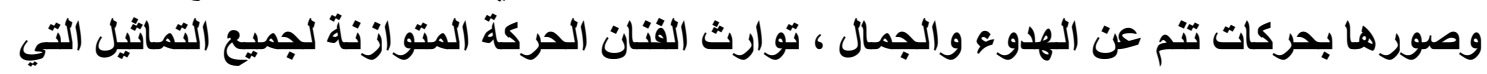

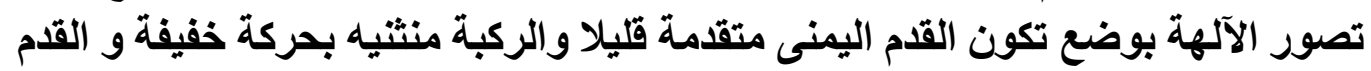

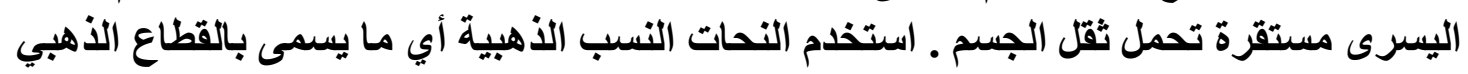

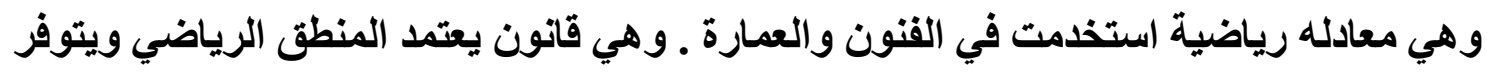

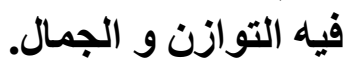

استخدم الفنان الإغريقي الجسم البشري الجميل الخالي من العيوب للتعبير عن شكل الآلهة ,

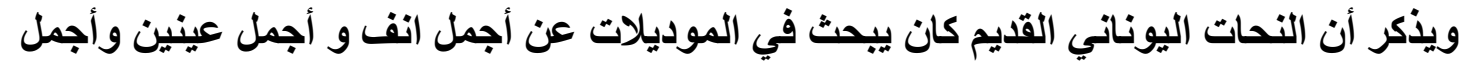

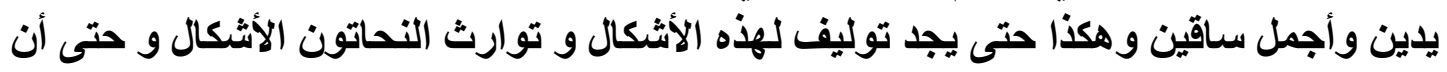

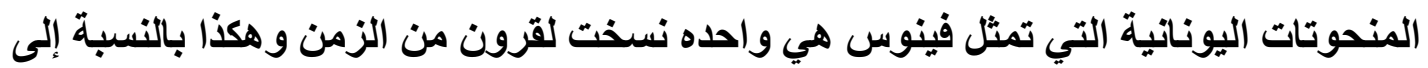

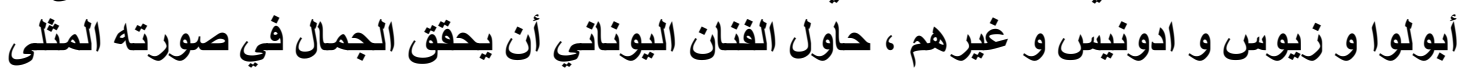

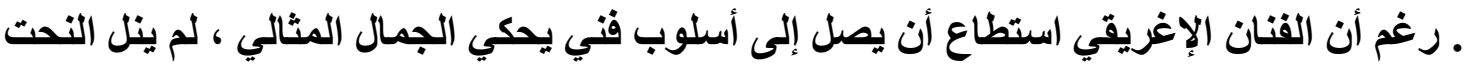

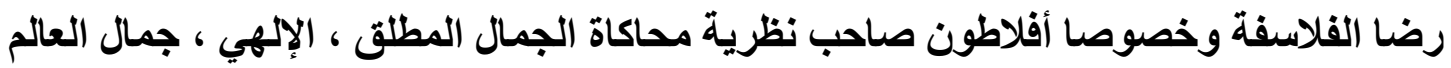

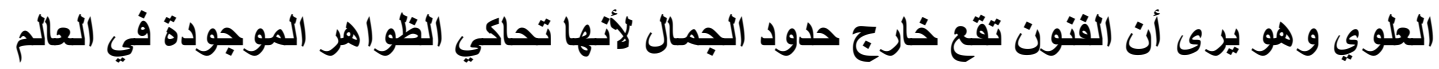

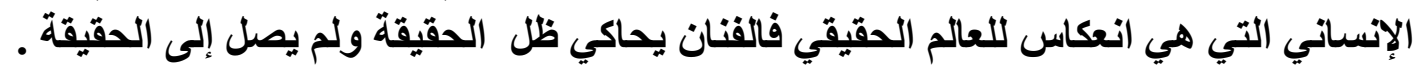

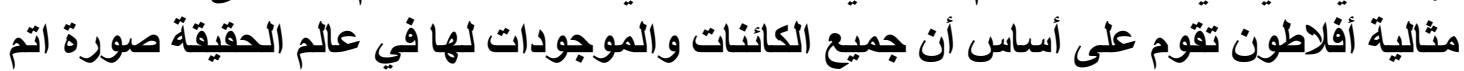

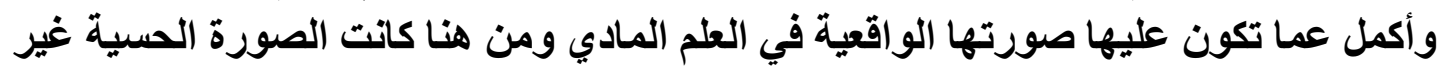
مكتملة مثل الأصل الموجود في عالم الآلهاهة عالم الجمال المطلق.

تسعى فكرة الجمال في القلسفة اليونانية إلى الكمال و التوازن بين الثكل والمضمون ، وامتازت الأعمال الفتية بالأفكار التبيلة وصارت قوة التفكير العقلاني والمثالي هما المعيار للجمال . أرتبط العقل بالاتزان وأتصف بالنسبة والتناسب .حيث ظهر الاهتمام بالنسبة الاقيقة في بناء جسم الإنسان وكذلك في الهياكل المعمارية ـ وقد أثرت القلسفة والدين في الفن اليوناني القديم

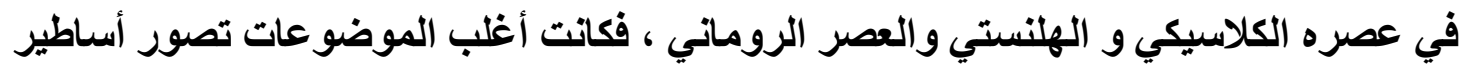

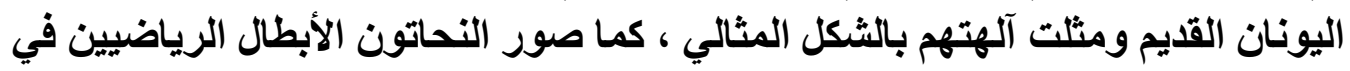
الشجاعة والنبل أو موضوعات تمثل الحياة اليومية . 
أمتاز النصف الثاني من القرن الرابع قبل الميلاد بسيادة النزعة الحسية ، وصارت الفنون أكثر

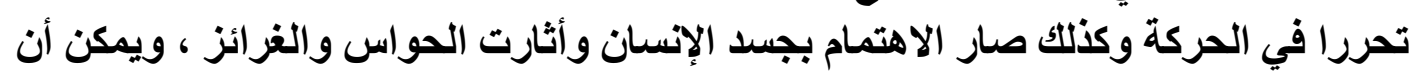

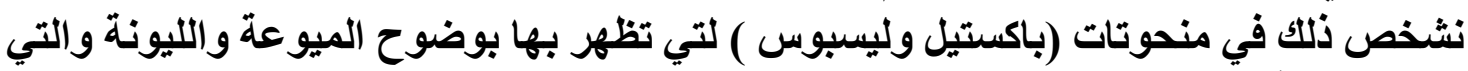

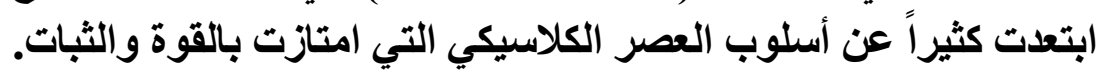

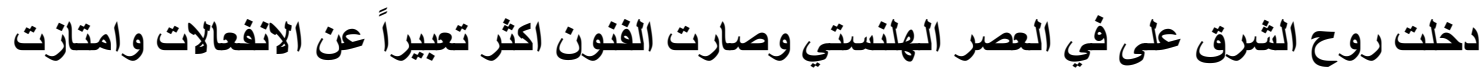

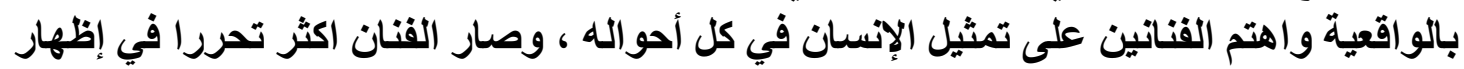

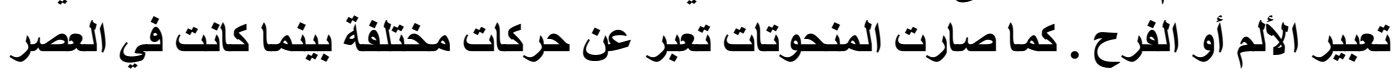

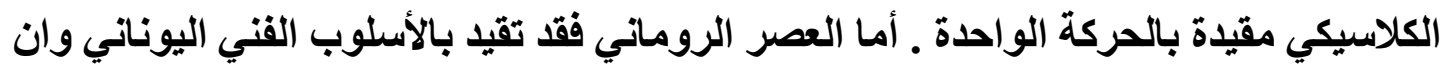

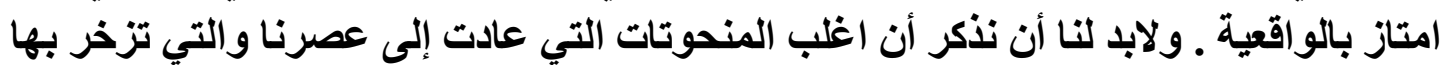

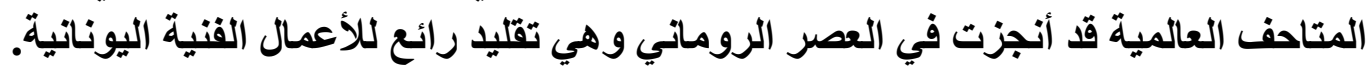

\section{الهوامش}

1

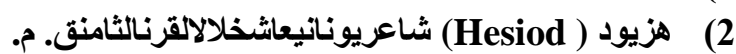

3) 4) هذهالنظريةليستنظريةرائدةفيالفكر الإنساني، انماهيمستمدةمنالفكر السومريالقديم.

(5 )

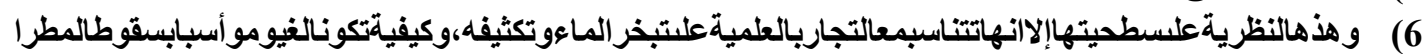

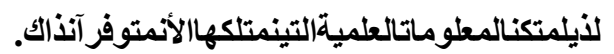

7)

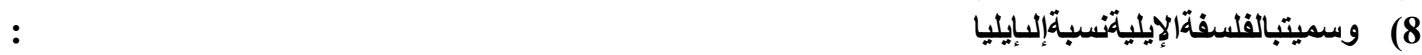

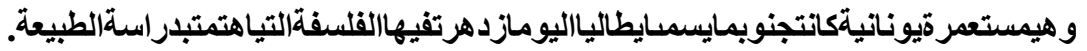

9

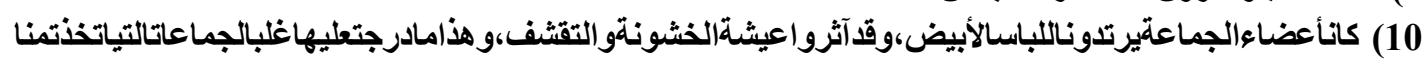

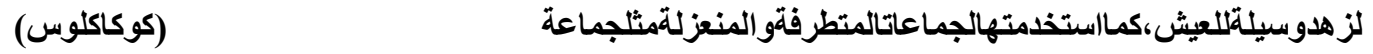

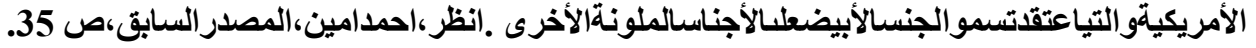

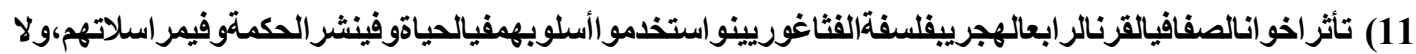
)

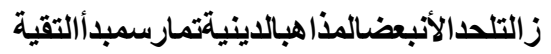

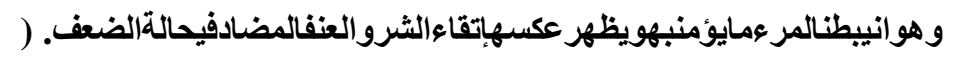

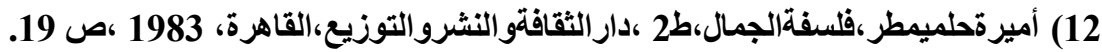

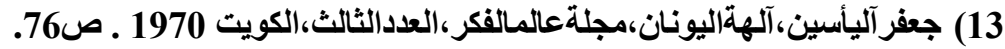

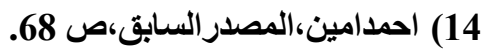

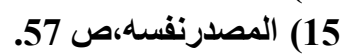

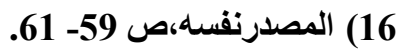

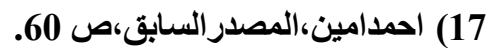

18) اللوغوسلفظة|غريقيةتعنيطمالقو انين ( المنطق ) ،و هو عندأفلاطونوأرسطوطاليس، أحدالمبادئائالأساسيةفيالفلسفة.

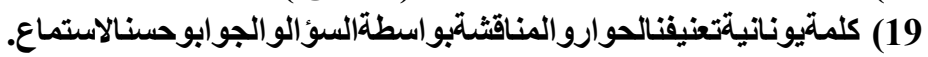




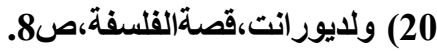

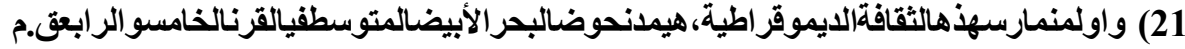

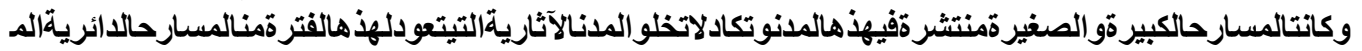

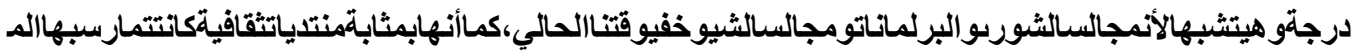

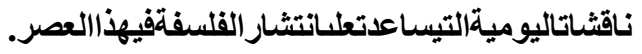

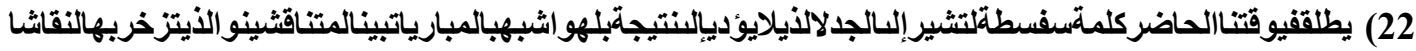

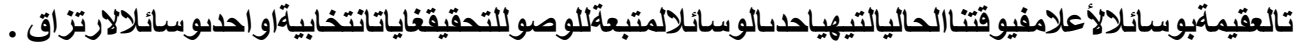

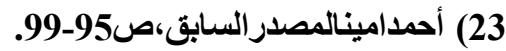

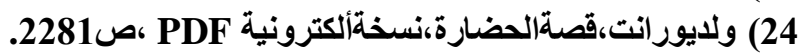

Foxit Software Company,2004-2007 for Evalution .iilas.com • 25) الطاهروعزوز،مناهجالفلسفة،المركز الثقافيالعربي،بيروت 1990 ـ ص ص 27.

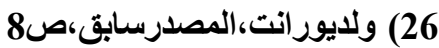

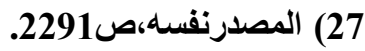

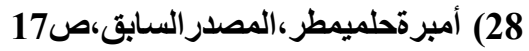

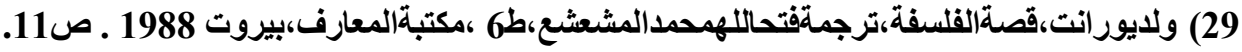

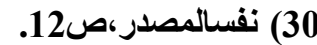

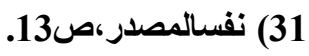

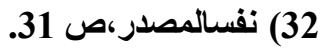

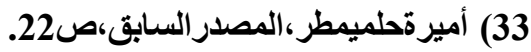

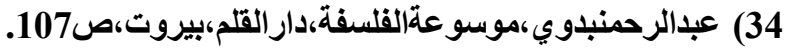

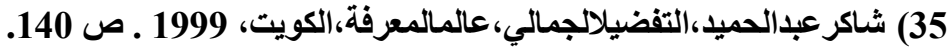

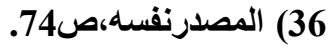
37) ولايورانت ـ المصدر السابق،صونفئ.67.

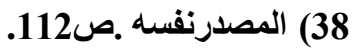

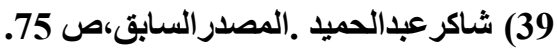

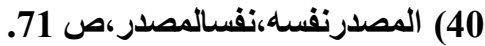

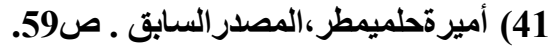

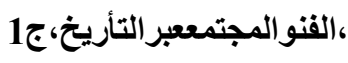
الفنوا المجتمعبر التأريخ

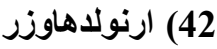

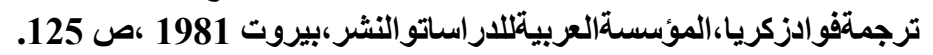

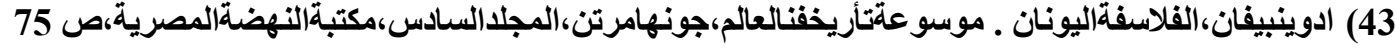

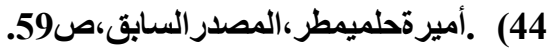

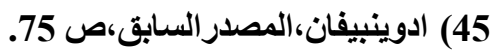

جيزاريختر ، الفنالإغريقي،مقدمةفيالفنالإغريقي،ترجمةجمالالحر امي،دارالأمانيللطباعةو النشروالتوزيع،طرطوس،

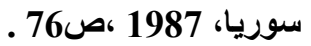

